\title{
Learning the Ropes of Platelet Count Regulation: Inherited Thrombocytopenias
}

\author{
Loredana Bury, Emanuela Falcinelli and Paolo Gresele *
}

check for

updates

Citation: Bury, L.; Falcinelli, E.; Gresele, P. Learning the Ropes of Platelet Count Regulation: Inherited Thrombocytopenias. J. Clin. Med. 2021, 10, 533. https://doi.org/ $10.3390 / \mathrm{jcm} 10030533$

Academic Editor: Hugo ten Cate Received: 30 December 2020

Accepted: 25 January 2021

Published: 2 February 2021

Publisher's Note: MDPI stays neutral with regard to jurisdictional claims in published maps and institutional affiliations.

Copyright: (c) 2021 by the authors. Licensee MDPI, Basel, Switzerland. This article is an open access article distributed under the terms and conditions of the Creative Commons Attribution (CC BY) license (https:/ / creativecommons.org/licenses/by/ $4.0 /)$.
Department of Medicine and Surgery, Section of Internal and Cardiovascular Medicine, University of Perugia, Centro Didattico, Edificio B Piano 1, 06132 Perugia, Italy; loredana.bury@unipg.it (L.B.); emanuelafalcinelli@gmail.com (E.F.)

* Correspondence: paolo.gresele@unipg.it; Tel.: +39-075-578-3989; Fax: +39-075-571-6083

Abstract: Inherited thrombocytopenias (IT) are a group of hereditary disorders characterized by a reduced platelet count sometimes associated with abnormal platelet function, which can lead to bleeding but also to syndromic manifestations and predispositions to other disorders. Currently at least 41 disorders caused by mutations in 42 different genes have been described. The pathogenic mechanisms of many forms of IT have been identified as well as the gene variants implicated in megakaryocyte maturation or platelet formation and clearance, while for several of them the pathogenic mechanism is still unknown. A range of therapeutic approaches are now available to improve survival and quality of life of patients with IT; it is thus important to recognize an IT and establish a precise diagnosis. ITs may be difficult to diagnose and an initial accurate clinical evaluation is mandatory. A combination of clinical and traditional laboratory approaches together with advanced sequencing techniques provide the highest rate of diagnostic success. Despite advancement in the diagnosis of IT, around 50\% of patients still do not receive a diagnosis, therefore further research in the field of ITs is warranted to further improve patient care.

Keywords: inherited thrombocytopenias; platelets; bleeding

\section{Introduction}

Platelets, or thrombocytes, are small and anuclear blood cells with discoid shape and a size of 1.5-3.0 $\mu \mathrm{m}$ which play a crucial function in primary hemostasis. Their normal life span is 9-10 days and total circulating mass $10^{12}$, thus about $10^{11}$ platelets are released each day from their bone marrow precursors, megakaryocytes, to maintain a normal circulating platelet count of 1.5 to $4 \times 10^{9} / \mathrm{L}$.

Inherited thrombocytopenias (ITs) are a heterogeneous group of congenital disorders characterized by a reduction of platelet number, a widely-variable bleeding diathesis, sometimes aggravated by associated impairment of platelet function, and frequently associated with additional defects, which may heavily impact patient lives.

ITs are rare diseases, with an estimated prevalence of 2.7 in 100,000 [1] although this figure is probably underestimated because they are often misdiagnosed as immune thrombocytopenia (ITP). A recent study on the assessment of the frequency of naturally occurring loss-of-function variants in genes associated with platelet disorders (52\% of which were associated with ITs) from a large genome aggregation database showed that $0.329 \%$ of subjects in the general population have a clinically meaningful loss-of-function variant in a platelet-associated gene [2].

The first IT, Bernard Soulier syndrome, was described in 1948 and subsequently only few additional forms were reported until Sanger sequencing first, and next generation sequencing later became widely applied rapidly bringing the known ITs from less than a dozen to currently at least 41 disorders caused by mutations in 42 different genes [3,4].

Despite these advancements however, it is estimated that genetic etiology of nearly $50 \%$ of patients with IT still remains undefined [5]. 


\section{Megakaryocytopoiesis and Platelet Production}

Platelets are produced by megakaryocytes (MKs), their giant bone marrow polyploid precursors, through a complex and highly regulated process. During maturation megakaryocytes become polyploid and accumulate massive amounts of proteins and membranes. Then, through a cytoskeletal-driven process, they extend long branching protrusions called proplatelets into sinusoidal blood vessels to release platelets [6]. However, under special conditions associated with strongly increased platelet turnover, platelets can be released through megakaryocyte rupture [7]. More recently, based on the calculation of the rate of proplatelet formation required for physiological platelet replacement, it has been suggested that membrane budding, rather than proplatelet formation, supplies the majority of the platelet biomass in vivo [8]. The release of platelets in lungs by megakaryocytes entered in blood and disintegrated by the impact with the pulmonary microcirculation has also been shown, but its relevance for platelet production is a matter of controversy [9].

The process of megakaryopoiesis involves multiple genes, coding for transcription factors, cytoskeletal proteins, membrane receptors and signaling proteins, which regulate megakaryocyte differentiation and platelet formation and release. Variants in any of these genes may cause IT.

\section{Hereditary Disorders of Platelet Number}

Given the wide heterogeneity of IT, there is no consensus on their classification, and several criteria have been proposed, such as on clinical features (e.g., age at presentation, severity, associated developmental abnormalities), platelet size or inheritance pattern (e.g., autosomal dominant, autosomal recessive and X-linked) $[4,10,11]$.

Here we have grouped them according to the pathogenic mechanisms of thrombocytopenia.

ITs are primarily caused by mutations in genes involved in megakaryocyte differentiation, maturation and platelet production [12] (Table 1, Figure 1).

Table 1. IT classified based on the defective step of platelet count regulation involved.

\begin{tabular}{|c|c|c|c|c|}
\hline $\begin{array}{l}\text { Defective Step of } \\
\text { Thrombopoiesis }\end{array}$ & $\begin{array}{l}\text { Affected } \\
\text { Gene }\end{array}$ & Disorder & Pathogenic Mechanism (Reference) & $\begin{array}{l}\text { Additional Features } \\
\text { (e.g., Syndromic } \\
\text { Manifestations, } \\
\text { Predisposition) }\end{array}$ \\
\hline & ANKRD26 & $\begin{array}{l}\text { ANKRD26-related } \\
\text { thrombocytopenia }\end{array}$ & $\begin{array}{l}\text { Loss of ANKRD26 silencing during the last } \\
\text { phases of megakaryocytopoiesis causes } \\
\text { ERK1/2 phosphorylation that interferes } \\
\text { with megakaryocyte maturation [13] }\end{array}$ & $\begin{array}{l}\text { Predisposition to } \\
\text { hematological malignancies }\end{array}$ \\
\hline & ETV6 & $\begin{array}{l}\text { ETV6-related } \\
\text { thrombocytopenia }\end{array}$ & $\begin{array}{l}\text { ETV6 is a transcriptional repressor that } \\
\text { promotes the late phases of } \\
\text { megakaryopoiesis. Mutations in ETV6 } \\
\text { cause defective megakaryocyte maturation } \\
\text { and impaired proplatelet formation [14] }\end{array}$ & $\begin{array}{l}\text { Predisposition to } \\
\text { hematological malignancies }\end{array}$ \\
\hline & FLI1 & $\begin{array}{l}\text { FLI1-related } \\
\text { thrombocytopenia }\end{array}$ & \multirow{2}{*}{$\begin{array}{l}\text { FLI1 is a transcription factor regulating } \\
\text { many genes associated with } \\
\text { megakaryocyte development. Therefore, } \\
\text { FLI1 mutations promote defective } \\
\text { megakaryocyte maturation [15] }\end{array}$} & Not reported \\
\hline & $\begin{array}{c}\text { FLI1 } \\
\text { deletion }\end{array}$ & $\begin{array}{l}\text { Paris-Trousseau } \\
\text { syndrome/Jacobsen } \\
\text { syndrome }\end{array}$ & & $\begin{array}{l}\text { Abnormalities of heart and } \\
\text { face, intellectual disabilities }\end{array}$ \\
\hline & FYB & $\begin{array}{l}\text { FYB-related } \\
\text { thrombocytopenia }\end{array}$ & $\begin{array}{l}\text { ADAP is a protein involved in the } \\
\text { remodeling of cytoskeleton. Mutations in } \\
\text { ADAP cause defective maturation of } \\
\text { megakaryocytes and clearance of } \\
\text { platelets [16] }\end{array}$ & Mild iron deficiency anemia \\
\hline \multirow[b]{2}{*}{$\begin{array}{l}\text { Defective } \\
\text { megakaryocyte } \\
\text { maturation }\end{array}$} & GATA1 & GATA1-relate disease & $\begin{array}{c}\text { GATA1 is a transcription factor regulating } \\
\text { many genes associated with } \\
\text { megakaryocyte development therefore } \\
\text { GATA1 defects cause alterations of } \\
\text { megakaryocyte maturation [17] }\end{array}$ & $\begin{array}{c}\text { Dyserythropoietic anemia, } \\
\text { beta-thalassemia, congenital } \\
\text { erythropoietic porphyria, } \\
\text { splenomegaly }\end{array}$ \\
\hline & GFI1B & $\begin{array}{l}\text { GFI1B-related } \\
\text { thrombocytopenia }\end{array}$ & $\begin{array}{l}\text { GFI1B is a transcription factor involved in } \\
\text { homeostasis of hematopoietic stem cells } \\
\text { and development of megakaryocytes } \\
\text { therefore GFI1B defects cause alterations of } \\
\text { megakaryocyte maturation [18] }\end{array}$ & Mild myelofibrosis \\
\hline
\end{tabular}


Table 1. Cont.

\begin{tabular}{|c|c|c|c|c|}
\hline $\begin{array}{l}\text { Defective Step of } \\
\text { Thrombopoiesis }\end{array}$ & $\begin{array}{l}\text { Affected } \\
\text { Gene }\end{array}$ & Disorder & Pathogenic Mechanism (Reference) & $\begin{array}{l}\text { Additional Features } \\
\text { (e.g., Syndromic } \\
\text { Manifestations, } \\
\text { Predisposition) }\end{array}$ \\
\hline & HOXA11 & \multirow{2}{*}{$\begin{array}{l}\text { Amegakaryocytic } \\
\text { thrombocytopenia with } \\
\text { radio-ulnar synostosis }\end{array}$} & $\begin{array}{c}\text { HOXA11 is a transcription factor involved } \\
\text { in the regulation of early hematopoiesis, its } \\
\text { defect causes reduced number of } \\
\text { megakaryocytes [19] }\end{array}$ & \multirow{2}{*}{$\begin{array}{c}\text { Bilateral radioulnar synostosis, } \\
\text { severe bone marrow failure } \\
\text { culminating } \\
\text { in aplastic anemia in majority } \\
\text { of cases, cardiac and renal } \\
\text { malformations, hearing loss, } \\
\text { clinodactyly, skeletal } \\
\text { abnormalities, pancytopenia }\end{array}$} \\
\hline & MECOM & & $\begin{array}{c}\text { MECOM is a transcription factor involved } \\
\text { in the regulation of early hematopoiesis, its } \\
\text { defect causes reduced number of } \\
\text { megakaryocytes [20] }\end{array}$ & \\
\hline & IKZF5 & $\begin{array}{l}\text { IKZF5-related } \\
\text { thrombocytopenia }\end{array}$ & $\begin{array}{l}\text { IKZF5 is a previously unknown } \\
\text { transcriptional regulator of } \\
\text { megakaryopoiesis [21] }\end{array}$ & Not reported \\
\hline & MPL & $\begin{array}{l}\text { Congenital } \\
\text { amegakaryocytic } \\
\text { thrombocytopenia }\end{array}$ & $\begin{array}{l}\text { MPL is the receptor for thrombopoietin. } \\
\text { MPL defects cause impaired } \\
\text { thrombopoietin binding and thus impaired } \\
\text { megakaryocyte maturation [22] }\end{array}$ & Acquired bone marrow aplasia \\
\hline & NBEAL2 & Gray platelet syndrome & $\begin{array}{c}\text { Mutations in NBEAL2 cause impaired } \\
\text { megakaryocyte maturation however its } \\
\text { role in megakaryocytopoiesis is not } \\
\text { clear [23] }\end{array}$ & $\begin{array}{c}\text { Myelofibrosis, immune } \\
\text { dysregulation (autoimmune } \\
\text { diseases, positive } \\
\text { autoantibodies, reduced } \\
\text { leukocyte counts), } \\
\text { proinflammatory profile }\end{array}$ \\
\hline & RBM8A & $\begin{array}{l}\text { Thrombocytopenia-absent } \\
\text { radius }\end{array}$ & $\begin{array}{c}\text { RBM8A is a protein of the exon-junction } \\
\text { complex involved in RNA processing. It } \\
\text { has been hypothesized that RBM8A defects } \\
\text { cause wrong mRNA processing of } \\
\text { unknown components of the TPO-MPL } \\
\text { pathway impairing megakaryocyte } \\
\text { maturation [24] }\end{array}$ & $\begin{array}{l}\text { Bilateral radial aplasia, } \\
\text { anemia, skeletal, urogenital, } \\
\text { kidney, heart defects }\end{array}$ \\
\hline & RUNX1 & $\begin{array}{l}\text { Familial platelet disorder } \\
\text { with predisposition to } \\
\text { hematological } \\
\text { malignancies }\end{array}$ & $\begin{array}{l}\text { RUNX1 is a transcription factor regulating } \\
\text { many genes associated with } \\
\text { megakaryocyte development therefore } \\
\text { RUNX1 mutations promote defective } \\
\text { megakaryocyte maturation [25] }\end{array}$ & $\begin{array}{l}\text { Predisposition to } \\
\text { hematological malignancies }\end{array}$ \\
\hline & THPO & THPO-related disease & $\begin{array}{c}\text { THPO is the gene for thrombopoietin, } \\
\text { essential for hematopoietic stem cell } \\
\text { survival and megakaryocyte maturation } \\
\text { [26] }\end{array}$ & Bone marrow aplasia \\
\hline & ACTB & $\begin{array}{l}\text { Baraitser-Winter } \\
\text { syndrome } 1 \text { with } \\
\text { macrothrombocytopenia }\end{array}$ & $\begin{array}{c}\text { Mutations in } \beta \text {-cytoplasmic actin inhibit } \\
\text { the final stages of platelet maturation by } \\
\text { compromising microtubule organization } \\
\text { [27] }\end{array}$ & $\begin{array}{l}\text { Microcephaly, facial anomalies, } \\
\text { mild intellectual disability, } \\
\text { developmental delay }\end{array}$ \\
\hline & ACTN1 & $\begin{array}{l}\text { ACTN1-related } \\
\text { thrombocytopenia }\end{array}$ & $\begin{array}{l}\text { ACTN-1 is involved in cytoskeletal } \\
\text { remodeling, defects in ACTN-1 cause } \\
\text { defective proplatelet formation [28] }\end{array}$ & Not reported \\
\hline & ARPC1B & $\begin{array}{l}\text { Platelet abnormalities } \\
\text { with eosinophilia and } \\
\text { immune-mediated } \\
\text { inflammatory disease }\end{array}$ & $\begin{array}{l}\text { The actin-related protein } 2 / 3 \text { complex } \\
\text { (Arp2/3) is a regulator of the actin } \\
\text { cytoskeleton and its mutation causes } \\
\text { impaired proplatelet formation [29] }\end{array}$ & $\begin{array}{c}\text { Immunodeficiency, systemic } \\
\text { inflammation, vasculitis, } \\
\text { inflammatory colitis, } \\
\text { eosinophilia, eczema, } \\
\text { lymphadenomegaly, } \\
\text { hepato-splenomegaly, growth } \\
\text { failure }\end{array}$ \\
\hline & CYCS & $\begin{array}{l}\text { CYCS-related } \\
\text { thrombocytopenia }\end{array}$ & $\begin{array}{l}\text { CYCS is a mitochondrial protein with a } \\
\text { role in respiration and apoptosis. } \\
\text { Mutations in CYCS cause ectopic } \\
\text { premature proplatelet formation with an } \\
\text { unknown mechanism [30] }\end{array}$ & Not reported \\
\hline & DIAPH1 & $\begin{array}{l}\text { DIAPH1-related } \\
\text { thrombocytopenia }\end{array}$ & $\begin{array}{l}\text { DIAPH1 is involved in cytoskeletal } \\
\text { remodeling, defects in DIAPH1 cause } \\
\text { defective proplatelet formation [31] }\end{array}$ & Hearing loss \\
\hline $\begin{array}{l}\text { Defective platelet } \\
\text { produc- } \\
\text { tion/increased } \\
\text { clearance }\end{array}$ & FLNA & $\begin{array}{l}\text { FLNA-related } \\
\text { thrombocytopenia }\end{array}$ & $\begin{array}{l}\text { Filamin A is involved in cytoskeletal } \\
\text { remodeling, defects in FLNA cause } \\
\text { defective proplatelet formation [32] }\end{array}$ & $\begin{array}{l}\text { Periventricular nodular } \\
\text { heterotopia and } \\
\text { otopalatodigital syndrome } \\
\text { spectrum of disorders }\end{array}$ \\
\hline
\end{tabular}


Table 1. Cont.

\begin{tabular}{|c|c|c|c|c|}
\hline $\begin{array}{l}\text { Defective Step of } \\
\text { Thrombopoiesis }\end{array}$ & $\begin{array}{l}\text { Affected } \\
\text { Gene }\end{array}$ & Disorder & Pathogenic Mechanism (Reference) & $\begin{array}{l}\text { Additional Features } \\
\text { (e.g., Syndromic } \\
\text { Manifestations, } \\
\text { Predisposition) }\end{array}$ \\
\hline & \multirow{2}{*}{$\begin{array}{l}\text { GP1BA, } \\
\text { GP1BB, GP9 } \\
\text { (loss of } \\
\text { function) }\end{array}$} & $\begin{array}{c}\text { Bernard-Soulier } \\
\text { syndrome monoallelic }\end{array}$ & \multirow{2}{*}{$\begin{array}{l}\text { The intracellular portion of the GPIb/IX/V } \\
\text { complex links the receptor to the } \\
\text { cytoskeleton. Disruption of this link causes } \\
\text { impaired proplatelet formation [33] }\end{array}$} & \multirow[t]{2}{*}{ Not reported } \\
\hline & & $\begin{array}{l}\text { Bernard-Soulier } \\
\text { syndrome biallelic }\end{array}$ & & \\
\hline & $\begin{array}{l}\text { GP1BA } \\
\text { (gain of } \\
\text { function) }\end{array}$ & $\begin{array}{l}\text { Platelet-type von } \\
\text { Willebrand disease }\end{array}$ & $\begin{array}{c}\text { The extracellular portion of the GPIb/IX/V } \\
\text { complex binds VWF. Constitutive binding } \\
\text { of VWF to its receptor triggers the Src } \\
\text { kinases pathway causing impaired } \\
\text { proplatelet formation, ectopic platelet } \\
\text { production and increased platelet } \\
\text { clearance [34] }\end{array}$ & Not reported \\
\hline & $\begin{array}{l}\text { ITGA2B, } \\
\text { ITGB3 }\end{array}$ & $\begin{array}{l}\text { ITGA2B/ITGB3-related } \\
\text { thrombocytopenia }\end{array}$ & $\begin{array}{l}\text { Constitutive activation of } \alpha_{\mathrm{IIb}} \beta_{3} \text { causes } \\
\text { cytoskeletal perturbation leading to } \\
\text { impaired proplatelet formation }[35,36]\end{array}$ & Not reported \\
\hline & KDSR & $\begin{array}{c}\text { Thrombocytopenia and } \\
\text { erythrokeraderma }\end{array}$ & $\begin{array}{c}\text { KDSR is an essential enzyme for de novo } \\
\text { sphingolipid synthesis, this suggests an } \\
\text { important role for sphingolipids as } \\
\text { regulators of cytoskeletal organization } \\
\text { during megakaryopoiesis and proplatelet } \\
\text { formation [37] }\end{array}$ & $\begin{array}{c}\text { Dermatologic involvement } \\
\text { ranging from } \\
\text { hyperkeratosis / } \\
\text { erythema to } \\
\text { ichthyosis. One family with no } \\
\text { or very mild } \\
\text { skin lesions but associated } \\
\text { anemia has been } \\
\text { reported }\end{array}$ \\
\hline & MYH9 & MYH9-related disorder & $\begin{array}{c}\text { MYH9 regulates cytoskeleton remodeling } \\
\text { and mediates signal transduction } \\
\text { pathways involved in proplatelet } \\
\text { formation. Abnormalities of MYH9 cause } \\
\text { hyperactivation of the Rho/ROCK } \\
\text { pathway causing ectopic platelet formation } \\
\text { [38] }\end{array}$ & $\begin{array}{l}\text { Kidney disease, cataract, } \\
\text { deafness, elevated liver } \\
\text { enzymes }\end{array}$ \\
\hline & MPIG6B & $\begin{array}{l}\text { Thrombocytopenia, } \\
\text { anemia and myelofibrosis }\end{array}$ & $\begin{array}{l}\text { G6b-B is a transmembrane receptor with an } \\
\text { ITIM motif with a not well defined role in } \\
\text { proplatelet formation [39] }\end{array}$ & $\begin{array}{l}\text { Microcitic anemia, } \\
\text { myelofibrosis, leukocytosis } \\
\text { may be present }\end{array}$ \\
\hline & PRKACG & $\begin{array}{l}\text { PRKACG-related } \\
\text { thrombocytopenia }\end{array}$ & $\begin{array}{l}\text { PKA activates many proteins involved in } \\
\text { megakaryocyte and platelet function, } \\
\text { among them FLNa and GPIb } \beta \text { therefore its } \\
\text { dysfunction causes impaired proplatelet } \\
\text { formation [40] }\end{array}$ & Not reported \\
\hline & STIM1 & Stormorken syndrome & $\begin{array}{l}\text { STIM1 mutations cause a constitutively } \\
\text { active store operated } \mathrm{Ca}^{2+} \text { release-activated } \\
\mathrm{Ca}^{2+}(\mathrm{CRAC}) \text { channel which triggers } \mathrm{Ca}^{2+} \\
\text { entry with consequent increased clearance } \\
\text { of activated platelets [41] }\end{array}$ & $\begin{array}{l}\text { Tubular myopathy and } \\
\text { congenital myosis. Severe } \\
\text { immune dysfunction }\end{array}$ \\
\hline & TRPM7 & $\begin{array}{l}\text { TRPM7-related } \\
\text { thrombocytopenia }\end{array}$ & $\begin{array}{l}\text { Defects of the } \mathrm{Mg}^{2+} \text { channel TRPM7, a } \\
\text { regulator of embryonic development and } \\
\text { cell survival, cause cytoskeletal alterations } \\
\text { resulting in impaired proplatelet formation } \\
\text { [42] }\end{array}$ & Atrial fibrillation \\
\hline & TPM4 & $\begin{array}{l}\text { TPM4-related } \\
\text { thrombocytopenia }\end{array}$ & $\begin{array}{l}\text { Tropomyosin } 4 \text { is an actin cytoskeletal } \\
\text { regulator. Insufficient TPM4 expression in } \\
\text { human and mouse megakaryocytes } \\
\text { resulted in a defect in the terminal stages } \\
\text { of platelet production [43] }\end{array}$ & Not reported \\
\hline & TUBB1 & $\begin{array}{l}\text { TUBB1-related } \\
\text { thrombocytopenia }\end{array}$ & $\begin{array}{l}\text { Tubulin beta1 is a major component of } \\
\text { microtubules therefore defects in TUBB1 } \\
\text { cause impaired proplatelet formation }[44]\end{array}$ & Not reported \\
\hline
\end{tabular}


Table 1. Cont.

\begin{tabular}{|c|c|c|c|c|}
\hline $\begin{array}{l}\text { Defective Step of } \\
\text { Thrombopoiesis }\end{array}$ & $\begin{array}{l}\text { Affected } \\
\text { Gene }\end{array}$ & Disorder & Pathogenic Mechanism (Reference) & $\begin{array}{l}\text { Additional Features } \\
\text { (e.g., Syndromic } \\
\text { Manifestations, } \\
\text { Predisposition) }\end{array}$ \\
\hline & \multirow[t]{2}{*}{ WAS } & $\begin{array}{l}\text { Wiskott-Aldrich } \\
\text { syndrome }\end{array}$ & \multirow{2}{*}{$\begin{array}{l}\text { The WASP protein is a regulator of the } \\
\text { actin cytoskeleton and its defect causes } \\
\text { ectopic platelet formation and increased } \\
\text { platelet clearance [ } 45]\end{array}$} & $\begin{array}{l}\text { Immunodeficiency, } \\
\text { hematopoietic malignancies, } \\
\text { eczema, autoimmune } \\
\text { hemolytic anemia. }\end{array}$ \\
\hline & & $\begin{array}{c}\text { X-linked } \\
\text { thrombocytopenia }\end{array}$ & & Not reported \\
\hline \multirow{6}{*}{$\begin{array}{l}\text { Other/unknown } \\
\text { pathogenic } \\
\text { mechanism }\end{array}$} & $\begin{array}{l}\text { ABCG5, } \\
\text { ABCG8 }\end{array}$ & $\begin{array}{l}\text { Thrombocytopenia } \\
\text { associated with } \\
\text { sitosterolemia }\end{array}$ & $\begin{array}{c}\text { ABCG5 and ABCG8 regulate plant sterol } \\
\text { and cholesterol absorption. It is supposed } \\
\text { that sterol-enriched platelets are more } \\
\text { rapidly cleared [46] }\end{array}$ & $\begin{array}{c}\text { Xanthomas and pre-mature } \\
\text { coronary atherosclerosis due } \\
\text { to } \\
\text { hypercholesterolemia }\end{array}$ \\
\hline & CDC42 & $\begin{array}{l}\text { Takenouchi-Kosaki } \\
\text { syndrome with } \\
\text { macrothrombocytopenia }\end{array}$ & $\begin{array}{l}\text { CDC42 is a critical molecule in various } \\
\text { biological processes including the cell cycle, } \\
\text { cell division, and the formation of the actin } \\
\text { cytoskeleton [47] }\end{array}$ & $\begin{array}{c}\text { Defective growth and } \\
\text { psychomotor } \\
\text { development, intellectual } \\
\text { disability, facial } \\
\text { abnormalities, brain } \\
\text { malformation, } \\
\text { muscle tone } \\
\text { abnormalities, } \\
\text { immunodeficiency, eczema, } \\
\text { hearing/visual disability, } \\
\text { lymphedema, } \\
\text { cardiac, genitourinary, and/or } \\
\text { skeletal } \\
\text { malformations }\end{array}$ \\
\hline & GNE & $\begin{array}{l}\text { GNE-related } \\
\text { thrombocytopenia }\end{array}$ & $\begin{array}{l}\text { GNE encodes an enzyme involved in the } \\
\text { sialic acid biosynthesis pathway and it is } \\
\text { known that thrombocytopenia is associated } \\
\text { with increased platelet desialylation [48] }\end{array}$ & $\begin{array}{l}\text { Some patients presented } \\
\text { myopathy with } \\
\text { rimmed vacuoles with onset in } \\
\text { early adulthood }\end{array}$ \\
\hline & SLNF14 & $\begin{array}{l}\text { SLNF14-related } \\
\text { thrombocytopenia }\end{array}$ & $\begin{array}{c}\text { SLNF14 is an endoribonuclease and its role } \\
\text { in the generation of thrombocytopenia is } \\
\text { unknown [49] }\end{array}$ & Not reported \\
\hline & SRC & $\begin{array}{l}\text { SRC-related } \\
\text { thrombocytopenia }\end{array}$ & $\begin{array}{l}\text { Src-family kinase regulates multiple } \\
\text { signaling pathways, its role in the } \\
\text { generation of thrombocytopenia is } \\
\text { unknown [50] }\end{array}$ & $\begin{array}{c}\text { Myelofibrosis, bone } \\
\text { pathologies, bone marrow } \\
\text { dysplasia, splenomegaly, } \\
\text { congenital facial } \\
\text { dysmorphism }\end{array}$ \\
\hline & PTPRJ & $\begin{array}{l}\text { PTPRJ-related } \\
\text { thrombocytopenia }\end{array}$ & $\begin{array}{l}\text { PTPRJ is a protein tyrosine phosphatase } \\
\text { expressed abundantly in platelets and } \\
\text { megakaryocytes, its role in the generation } \\
\text { of thrombocytopenia is unknown [51] }\end{array}$ & None \\
\hline
\end{tabular}



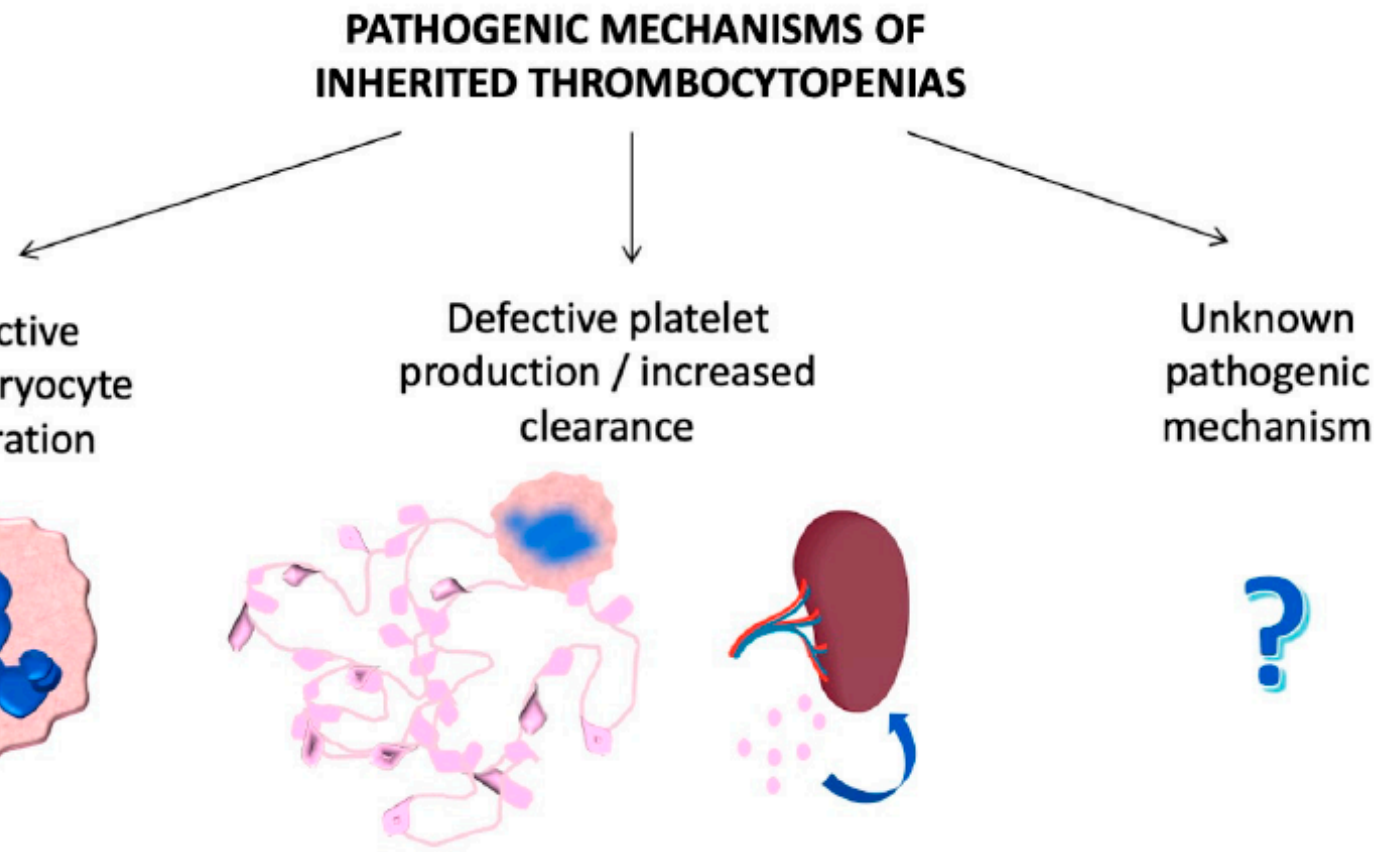

\section{Unknown mechanism}

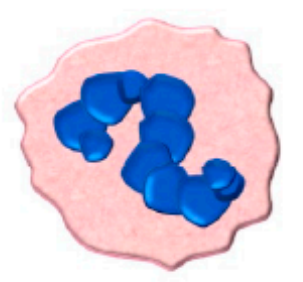

\section{megakaryocyte maturation}
ANKRD26, ETV6, FLI1, FYB, GATA1, GFI1B, HOXA11, MECOM, IKZF5, MPL, NBEAL2, RBM8A, RUNX1, THPO
ACTB, ACTN1, ARPC1B, CYCS, DIAPH1, FLNA, GP1BA, GP1BB, GP9, ITGA2B, ITGB3, KDSR, MYH9, MPIG6B, PRKACG, STIM1, TRPM7, TPM4, TUBB1, WAS

\author{
ABCG5, ABCG8, CDC42, \\ GNE, SLNF14, SRC, \\ PTPRJ
}

Figure 1. Genes involved in inherited thrombocytopenias classified according to the pathogenic mechanisms.

\subsection{ITs Caused by Defective Megakaryocyte Maturation and Differentiation}

ITs due to defective differentiation of hematopoietic stem cells (HSCs) into MKs are characterized by the absence or severe reduction in the number of bone marrow MKs.

ITs caused by altered MK maturation are characterized by a normal or increased number of bone marrow MKs which however are immature, dysmorphic and dysfunctional and include at least 14 different forms. Eight of these are caused by mutations of transcription factors with a key role in megakaryopoiesis, i.e., RUNX1, FLI1, GATA1, GFI1b, ETV6, HOXA11, MECOM, IKZF5. These transcription factors regulate, as activator or repressor, the expression of numerous genes, therefore these disorders are characterized by the concurrent alterations of multiple steps in $\mathrm{MK}$ and platelet development. For instance, RUNX1 transactivates transcription factors involved in MK maturation, proteins of the MK cytoskeleton (MYH9, MYL9, MYH10) or implicated in $\alpha$ and dense granule development (RAB1B, PLDN, NFE2) and members of the MK/platelet signaling pathways (ANKRD26, MPL, PRKCQ, ALOX12, PCTP) [17]. FLI1 activates the transcription of several genes associated with the production of mature $\mathrm{MKs}$, including $M P L$, ITGA2B, GP9, GPIBA and PF4 [52]. Thrombocytopenia of TCPT/JBS, caused by deletions of the long arm of chromosome 11q, is due to reduced expression of FLI1 which is included in the deleted region.

Disorders caused by GATA1 and GFI1B mutations are associated with erythrocyte abnormalities showing the essential role of these transcription factors in controlling also red cell production. Moreover, the predisposition to haematological neoplasms of patients 
with RUNX1 and ETV6 variants highlights how these pathogenic variants also disrupt the homeostasis of myeloid and multipotent progenitors, respectively. Amegakaryocytic thrombocytopenia with radio-ulnar synostosis (ATRUS), a rare IT which often evolves in trilinear bone marrow failure, is due to variants in HOXA11 and MECOM, members of a family of genes encoding for DNA-binding proteins involved in the regulation of early hematopoiesis [53]. IKZF5 is a transcription factor with a non-clear role in hematopoiesis and is involved in IKZF5-RT [21].

Variants in THPO, the gene coding for thrombopoietin, a growth factor essential for hematopoietic stem cell survival and megakaryocyte maturation, and in MPL, coding for the thrombopoietin receptor, cause THPO-related thrombocytopenia (THPO-RT) and congenital amegakaryocytic thrombocytopenia (CAMT), respectively. FYB-RT is caused by variants in the FYB gene, coding for a cytoskeletal protein [16], and thrombocytopeniaabsent radius is caused by variants in RBM8A, a protein of the exon-junction complex [24]. Finally, ANKRD26 and NBEAL2, proteins with an unknown role, are involved in ANKRD26RT [13] and Gray platelet syndrome (GPS) [23], respectively.

\subsection{ITs Caused by Defective Platelet Production/Clearance}

ITs derived from defects of the generation of proplatelets from mature MKs and/or of the conversion of proplatelets to platelets in the bloodstream are characterized by normal MK differentiation and maturation but by ectopic release of platelets in the bone marrow and/or increased clearance of platelets from the circulation. Most of these forms are associated with enlarged platelets and derive from mutations in genes encoding for components of the acto-myosin or microtubular cytoskeletal system, such as MYH9, ACTN1, FLNA, TPM4, TRPM7 or TUBB1, or from mutations of genes for the major membrane glycoprotein (GP) complexes GPIb/IX/V and GPIIb/IIIa that indirectly affect cytoskeletal structure or reorganization, i.e., like biallelic and monoallelic Bernard Soulier syndrome (BSS) and ITGA2B/ITGB3-RT. In the latter case macrothrombocytopenia results from the disruption of the interactions of integrins with the actomyosin cytoskeleton which is essential for preserving MK cytoskeletal structure and organization. For instance, ITGA2B/ITGB3-RT is due to gain-of-function variants resulting in the constitutive, inappropriate activation of GPIIb/IIIa triggering outside-in signaling with consequent altered remodeling of the actin cytoskeleton $[35,54,55]$. Another example is platelet type VWD, or pseudo von Willebrand, due to gain-of-function mutations that increase the affinity of GPIb $\alpha$ for VWF with the consequent triggering of the Src kinases pathway downstream of activated GPIb $\alpha$ [34].

Wiskott-Aldrich syndrome (WAS) is a syndromic IT and X-linked thrombocytopenia (XLT) is a milder variant with only isolated thrombocytopenia which derive from mutations in the WAS gene leading to defective expression or activity of its product WASp. WASp is expressed exclusively in hematopoietic cells and has a key role in actin polymerization and cytoskeleton rearrangement. Studies in mice have shown ineffective platelet production with ectopic proplatelet formation (PPF) within the bone marrow and impaired SDF1driven MK migration to the vascular niche [56]. The observation that splenectomy enhances the platelet count in WAS and XLT patients however, suggests that increased platelet clearance is also an important mechanism of thrombocytopenia in these disorders.

An additional group of IT belonging to those caused by impaired platelet production is due to variants in genes not directly involved in proplatelet formation, such as CYCS$\mathrm{RT}$, caused by dysfunction of a mitochondrial protein that causes thrombocytopenia by enhancing an apoptotic pathway [30], or PRKACG-RT, leading to dysfunction of PKA, which activates many proteins involved in megakaryocyte and platelet function such as $\mathrm{FLNa}$ and GPIb $\beta$ [40]. The Stormorken syndrome is due to gain of function mutations of STIM1 [57]. In these patients platelets circulate in an activated state due to a constitutively active store operated $\mathrm{Ca}^{2+}$ release-activated $\mathrm{Ca}^{2+}$ (CRAC) channel which triggers $\mathrm{Ca}^{2+}$ entry with consequent increased clearance of activated platelets by the spleen which causes a reduction in the number of circulating platelets [58]. 
Ectopic proplatelet formation in bone marrow is a peculiar mechanism causing thrombocytopenia in FYB, GP1BA (gain-of-function variants) and MYH9.

\subsection{ITs Caused by Unknown Pathogenic Mechanisms}

One last group of ITs is caused by variants in genes not known to be involved in megakaryocyte maturation or platelet production, and that cause thrombocytopenia by still unknown mechanisms.

An interesting IT is thrombocytopenia associated with sitosterolemia, a rare autosomal recessive disorder caused by mutations in two adjacent ATP-binding cassette transport genes ( $A B C G 5$ and $A B C G 8$ ) encoding proteins (sterolins-1 and -2) that pump sterols out of cells [59]. Among the manifestations of this complex disorder due to the accumulation of sterols in plasma and cell membranes are haematological abnormalities, including thrombocytopenia, provoked by the increased stiffness of sterol-enriched membranes with possible enhanced susceptibility to lysis and rupture [60].

Another recently discovered gene causing IT is SLFN14, an endoribonuclease degrading mRNA $[49,61,62]$. Alongside reduced platelet number, these patients show increased platelet clearance and platelet dysfunction. However, the mechanism through which mutations in SLFN14 induce enhanced platelet turnover and abnormal platelet function is unknown. Similarly, the pathogenic mechanisms of one of the most recently reported causative genes of IT, GNE, are unknown. Mutations of GNE, the gene encoding Glucosamine (UDP-NAcetyl)-2-Epimerase/N-Acetylmannosamine kinase, cause sialuria and hereditary inclusion body myopathy [63] but are also associated with severe thrombocytopenia characterized by shortened platelet lifespan, but the exact mechanisms have not been clarified [48].

\section{Diagnostic Approach}

\subsection{Introduction}

Patients referred for investigation of bleeding symptoms should undergo preliminary laboratory investigations including full blood count, prothrombin time, activated partial thromboplastin time and von Willebrand factor (VWF) screening tests (VWF antigen, ristocetin cofactor activity and factor VIII coagulant activity). If from full blood count thrombocytopenia is identified, a diagnostic work-up for IT should be pursued. If these are normal the presence of an inherited platelet function disorder (IPFD) should be explored. IPFD are listed under Table 2.

Table 2. Inherited platelet function disorders: disorders in which platelet dysfunction is the dominant phenotypic feature independent of platelet count.

\begin{tabular}{cccc}
\hline Disease & Inheritance & Gene & Bleeding \\
Diathesis & Severe \\
\hline $\begin{array}{c}\text { Arthrogryposis, renal dysfunction and } \\
\text { cholestasis }\end{array}$ & AR & VIPAS39 & RASGRP2 \\
\hline CalDAG-GEFI related platelet disorder & AR & CHS1 & Moderate-severe \\
\hline Cediak-Higashi Syndrome & AR & Unknown & Moderate-severe \\
\hline Combined alpha-delta granule deficiency & AR/AD & PTGSA & Mild-moderate \\
\hline COX-1 deficiency & AR/AD & Unknown & Mild-moderate \\
\hline Delta granule deficiency & AR/AD & ITGA2B, ITGB3 & Moderate-severe \\
\hline Glanzmann thrombasthenia & AR & GP4 & Mild \\
\hline Glycoprotein IV (GPIV) deficiency & AR & GP6 & Mild \\
\hline G platelet defect & AR & GNAS & Mild \\
\hline
\end{tabular}


Table 2. Cont.

\begin{tabular}{|c|c|c|c|}
\hline Disease & Inheritance & Gene & $\begin{array}{l}\text { Bleeding } \\
\text { Diathesis }\end{array}$ \\
\hline Hermansky-Pudlak syndrome & AR & $\begin{array}{c}\text { HPS1, ADTB3A, HPS3, HPS4, } \\
\text { HPS5, HPS6, DTNBP1, } \\
\text { BLOC1S3, AP3D1, BLOC1S6 }\end{array}$ & Moderate-severe \\
\hline Leukocyte adhesion deficiency, type III & AR & FERMT3 & Moderate-severe \\
\hline P2Y12 deficiency & AR & P2RY12 & Moderate-severe \\
\hline Phospholipase $\mathrm{A}_{2}\left(\mathrm{cPLA}_{2}\right)$ deficiency & not determined & PLA2G4A & Moderate-severe \\
\hline PKC $\delta$ deficiency & AR & PRKCD & Absent \\
\hline Primary secretion defect & $\mathrm{AR} / \mathrm{AD}$ & Unknown & Mild-moderate \\
\hline Quebec platelet disorder & $\mathrm{AD}$ & PLAU & Moderate-severe \\
\hline Scott syndrome & AR & TMEM16F & Mild-moderate \\
\hline Thromboxane A2 receptor defect & $\mathrm{AD}$ & $T B X A 2 R$ & Mild \\
\hline $\mathrm{T}_{\mathrm{x}}$ synthase deficiency & $\mathrm{AD} / \mathrm{AR}$ & TBXAS1 & Moderate \\
\hline
\end{tabular}

The diagnostic approach to ITs can be divided into two steps. The first is the recognition of the hereditary nature of thrombocytopenia, the second is the diagnosis of a specific disorder. In fact, ITs are often confused with acquired thrombocytopenias, leading many patients to receive futile and often dangerous treatments. Careful medical history and accurate evaluation of some simple laboratory parameters help to avoid misdiagnosis [64,65]. A diagnostic algorithm for inherited thrombocytopenias was proposed several years ago and it is still valid to orient towards specific disorders $[66,67]$. History and clinical examination are crucial for patients with syndromic forms, whereas cell counting and the examination of peripheral blood films may guide diagnosis in non-syndromic forms [68]. However, in most cases genetic studies are required to confirm the diagnostic suspicion $[3,69]$. Here we propose a diagnostic flow chart for diagnosis of IT.

\subsection{Clinical Examination}

The first step for IT diagnosis is a careful clinical evaluation of the proband, including the personal and family bleeding history. Treatment with drugs (continuous or intermittent), recent infection, previously diagnosed haematologic disease, nonhaematologic diseases known to decrease platelet counts (e.g., eclampsia, sepsis, DIC, anaphylactic shock, hypothermia, massive transfusions), recent live virus vaccination, poor nutritional status, pregnancy, recent organ transplantation from a donor sensitized to platelet alloantigens and recent transfusion of a platelet-containing product in an allosensitized recipient should be excluded. Thrombocytopenia and/or bleeding history in other family members support the hypothesis of an IT, however a negative family history does not exclude it because some forms are recessive or derive from de novo mutations.

The most severe ITs, such as congenital amegakaryocytic thrombocytopenia or biallelic BSS, are typically identified early in infancy because of bleeding diathesis, while for several ITs spontaneous bleeding is absent or very mild explaining why they are often recognized in adult life.

Besides hemorrhagic manifestations, physical examination should also explore other organs/systems abnormalities for syndromic ITs.

In most syndromic forms the associated manifestations are present since the first months of life, such as in CAMT, Jacobsen and Wiskott-Aldrich syndrome and thrombocytopenia with absent radii, while in others they may become apparent later in life, such as renal failure in MYH9-RD, and in the latter case their genetic origin may be missed. 


\subsection{Laboratory Tests}

At the first identification of thrombocytopenia, "pseudothrombocytopenia", a relatively common artifactual phenomenon caused by platelet clumping in the test tube due to the presence of EDTA (ethylenediaminetetraacetic acid) as anticoagulant accounting for $0.07 \%$ to $0.27 \%$ of all cases of isolated thrombocytopenia, should be excluded [70].

Evaluation of peripheral blood smears can guide the diagnostic workup because 29 of the 41 forms that have been identified so far display morphological abnormalities of platelets, granulocytes, and/or erythrocytes [68].

When platelet size is reduced, X-linked thrombocytopenia (XLT), WAS and ITs associated with variants in FYB and PTPRJ should be considered [71]. When platelet size is enhanced MYH9-RD, BSS, GPS, thrombocytopenia linked to DIAPH1, FLNA, GATA1, GNE, TUBB-1, GFI1b, PRKACG, SLF14, TRPM7, TPM4 and ACTN1, Paris-Trousseau thrombocytopenia, PT-VWD, ITGA2B/ITGB3-RT or thrombocytopenia associated with sitosterolemia should be considered. Among these, giant platelets characterize MYH9-RD, bBSS and TUBB1-RT. ITs associated with a normal platelet size instead are ATRUS, SRC-RT, TAR, thrombocytopenia and erythrokeraderma, CYCS-RT, FLI1-RT, IKZF5-RT, THPO-RT, ANKRD26-RT, CAMT, ETV6-RT and FPD/AML.

Abnormality of platelet granules may be observed in some ITs, with reduced or absent granules with enlarged platelets in GPS and GFI1b-RT and with reduced granules with normal-sized platelets in ANKRD26-RT [13,23,72].

Immunofluorescence performed on blood smears has recently been proposed as a method to identify defective membrane protein expression, disturbed distribution of cytoskeletal proteins, and reduction of $\alpha$ or delta granules, however this method requires interlaboratory validation [68].

Classic tests of platelet function, such as aggregometry (light transmission or impedance aggregometry), flow cytometry, secretion assays, electron microscopy and western blotting, may help for some ITs as subsequent steps in the diagnostic algorithm (Table 3) [18,73-75].

Table 3. Main features of inherited thrombocytopenias.

\begin{tabular}{|c|c|c|c|c|c|}
\hline Form & Disease & Inheritance & $\begin{array}{l}\text { Degree of Throm- } \\
\text { bocytopenia }\end{array}$ & Key Laboratory Features & References \\
\hline & $\begin{array}{l}\text { Amegakaryocytic } \\
\text { thrombocytopenia with } \\
\text { radio-ulnar synostosis } \\
\text { (ATRUS) }\end{array}$ & $\mathrm{AD}$ & severe & $\begin{array}{l}\text { Normal platelet size and } \\
\text { morphology }\end{array}$ & {$[19,20]$} \\
\hline & $\begin{array}{c}\text { Baraitser-Winter syndrome } \\
1 \text { with } \\
\text { macrothrombocytopenia }\end{array}$ & $\mathrm{AD}$ & absent & $\begin{array}{l}\text { Macrothrombocytopenia; } \\
\text { leukocytosis with eosinophilia, } \\
\text { leukopenia }\end{array}$ & [27] \\
\hline & $\begin{array}{l}\text { FLNA-related } \\
\text { thrombocytopenia }\end{array}$ & $X L$ & moderate & $\begin{array}{l}\text { Macrothrombocytopenia; } \\
\text { impaired platelet aggregation } \\
\text { GPVI-triggered; heterogeneous } \\
\alpha \text {-granules, occasionally giant; } \\
\text { abnormal distribution of FLNa }\end{array}$ & [32] \\
\hline & GATA-1-related disease & $X L$ & severe & $\begin{array}{l}\text { Macrothrombocytopenia; } \\
\text { reduced platelet aggregation by } \\
\text { collagen and ristocetin; reduced } \\
\alpha \text {-granule content and release }\end{array}$ & [17] \\
\hline & $\begin{array}{c}\text { GNE-related } \\
\text { thrombocytopenia }\end{array}$ & AR & $\begin{array}{l}\text { from mild to } \\
\text { severe }\end{array}$ & Macrothrombocytopenia & [48] \\
\hline Syndromic & Gray platelet syndrome & AR & moderate/severe & $\begin{array}{l}\text { Macrothrombocytopenia; grey } \\
\text { or pale platelets; } \\
\text { dyserytropoiesis; absence of } \\
\alpha \text {-granules; defective } \\
\text { TRAP-induced platelet } \\
\text { aggregation }\end{array}$ & [23] \\
\hline
\end{tabular}


Table 3. Cont

\begin{tabular}{|c|c|c|c|c|c|}
\hline Form & Disease & Inheritance & $\begin{array}{l}\text { Degree of Throm- } \\
\text { bocytopenia }\end{array}$ & Key Laboratory Features & References \\
\hline & $\begin{array}{l}\text { Paris-Trousseau } \\
\text { thrombocytopenia, Jacobsen } \\
\text { syndrome }\end{array}$ & $\mathrm{AD}$ & severe & $\begin{array}{c}\text { Macrothrombocytopenia; } \\
\text { defective platelet aggregation } \\
\text { by thrombin; giant } \alpha \text {-granules }\end{array}$ & [15] \\
\hline & $\begin{array}{l}\text { Platelet abnormalities with } \\
\text { eosinophilia and } \\
\text { immune-mediated } \\
\text { inflammatory disease }\end{array}$ & $\mathrm{AR}$ & moderate & $\begin{array}{l}\text { Small platelets; eosinophilia; } \\
\text { reduced platelet spreading; } \\
\text { decreased platelet dense } \\
\text { granules }\end{array}$ & [29] \\
\hline & $\begin{array}{l}\text { PTPRJ-related } \\
\text { thrombocytopenia }\end{array}$ & $\mathrm{AR}$ & moderate/severe & $\begin{array}{l}\text { Microthrombocytopenia; } \\
\text { impaired activation by the } \\
\text { GPVI-specific agonist convulxin } \\
\text { and the thrombin } \\
\text { receptor-activating peptide but } \\
\text { normal response to ADP }\end{array}$ & [51] \\
\hline & $\begin{array}{l}\text { SRC-related } \\
\text { thrombocytopenia }\end{array}$ & $\mathrm{AD}$ & moderate/severe & $\begin{array}{l}\text { Platelets deficient in granules } \\
\text { and rich in vacuoles }\end{array}$ & [50] \\
\hline & Stormorken syndrome & $\mathrm{AD}$ & moderate/severe & $\begin{array}{c}\text { Howell-Jolly bodies in red } \\
\text { blood cells; enhanced annexin V } \\
\text { binding, defective GPIIb/IIIa } \\
\text { activation (PAC-1) }\end{array}$ & [41] \\
\hline & $\begin{array}{l}\text { Takenouchi-Kosaki } \\
\text { syndrome with } \\
\text { macrothrombocytopenia }\end{array}$ & $\mathrm{AD}$ & absent & $\begin{array}{l}\text { Macrothrombocytopenia, } \\
\text { abnormal platelet spreading } \\
\text { and filopodia formation }\end{array}$ & [47] \\
\hline & $\begin{array}{l}\text { Thrombocytopenia-absent } \\
\text { radius syndrome (TAR) }\end{array}$ & $\mathrm{AR}$ & severe & $\begin{array}{l}\text { Normal platelet size and } \\
\text { morphology, thrombocytopenia }\end{array}$ & [24] \\
\hline & $\begin{array}{l}\text { Thrombocytopenia and } \\
\text { erythrokeraderma }\end{array}$ & $\mathrm{AR}$ & moderate & $\begin{array}{l}\text { Thrombocytopenia and } \\
\text { presence of } \\
\text { 3-keto-dihydrosphingosine in } \\
\text { plasma }\end{array}$ & [37] \\
\hline & $\begin{array}{l}\text { Thrombocytopenia, anemia } \\
\text { and myelofibrosis }\end{array}$ & $\mathrm{AR}$ & mild/moderate & $\begin{array}{l}\text { Macrothrombocytopenia, } \\
\text { anemia }\end{array}$ & [39] \\
\hline & Wiskott-Aldrich syndrome & $\mathrm{XL}$ & severe & $\begin{array}{c}\text { Microthrombocytopenia; } \\
\text { Reduced } \alpha / \delta \text { granules release }\end{array}$ & [45] \\
\hline & X-linked thrombocytopenia & $\mathrm{XL}$ & mild/moderate & $\begin{array}{c}\text { Microthrombocytopenia; } \\
\text { Reduced } \alpha / \delta \text { granules release }\end{array}$ & [45] \\
\hline \multirow{5}{*}{$\begin{array}{l}\text { Non- } \\
\text { syndromic }\end{array}$} & $\begin{array}{l}\text { ACTN1-related } \\
\text { thrombocytopenia }\end{array}$ & $\mathrm{AD}$ & mild & Macrothrombocytopenia & [28] \\
\hline & $\begin{array}{l}\text { Bernard Soulier syndrome } \\
\text { monoallelic } \\
\text { biallelic }\end{array}$ & $\begin{array}{l}\mathrm{AD} \\
\mathrm{AR}\end{array}$ & $\begin{array}{c}\text { mild } \\
\text { moderate/severe }\end{array}$ & $\begin{array}{l}\text { Macrothrombocytopenia; lack } \\
\text { of platelet agglutination to } \\
\text { ristocetin with normal } \\
\text { aggregation to other agonists; } \\
\text { severe reduction or complete } \\
\text { lack of GPIb/IX/V }\end{array}$ & [33] \\
\hline & $\begin{array}{l}\text { CYCS-related } \\
\text { thrombocytopenia }\end{array}$ & $\mathrm{AD}$ & mild & $\begin{array}{l}\text { Normal platelet size and } \\
\text { morphology }\end{array}$ & {$[30]$} \\
\hline & $\begin{array}{l}\text { FLI1-related } \\
\text { thrombocytopenia }\end{array}$ & $\mathrm{AD} / \mathrm{AR}$ & moderate & $\begin{array}{l}\text { Reduced platelet aggregation in } \\
\text { response to collagen and PAR-1 } \\
\text { agonists; } \delta \text {-granule deficiency }\end{array}$ & [15] \\
\hline & $\begin{array}{l}\text { FYB-related } \\
\text { thrombocytopenia }\end{array}$ & $\mathrm{AR}$ & moderate/severe & $\begin{array}{l}\text { Microthrombocytopenia; } \\
\text { increased expression of } \\
\text { P-selectin and PAC-1 by resting } \\
\text { platelets but impaired upon } \\
\text { stimulation with ADP }\end{array}$ & [16] \\
\hline
\end{tabular}


Table 3. Cont.

\begin{tabular}{|c|c|c|c|c|c|}
\hline Form & Disease & Inheritance & $\begin{array}{l}\text { Degree of Throm- } \\
\text { bocytopenia }\end{array}$ & Key Laboratory Features & References \\
\hline & $\begin{array}{l}\text { GFI1b-related } \\
\text { thrombocytopenia }\end{array}$ & $\mathrm{AD} / \mathrm{AR}$ & mild/moderate & $\begin{array}{l}\text { Macrothrombocytopenia; } \\
\text { dyserytropoiesis; reduced } \\
\alpha \text {-granule content and release; } \\
\text { diminished expression of } \\
\text { GPIb } \alpha \text {, red cell anisocytosis }\end{array}$ & [18] \\
\hline & $\begin{array}{l}\text { IKZF5-related } \\
\text { thrombocytopenia }\end{array}$ & $\mathrm{AD}$ & absent & $\begin{array}{c}\text { Thrombocytopenia; deficiency } \\
\text { of platelet alpha granules. }\end{array}$ & {$[21]$} \\
\hline & $\begin{array}{l}\text { ITGA2B/ITGB3-related } \\
\text { thrombocytopenia }\end{array}$ & $\mathrm{AD}$ & mild/moderate & $\begin{array}{l}\text { Macrothrombocytopenia; } \\
\text { reduced GPIIb/IIIa; defective } \\
\text { GPIIb/IIIa activation (PAC-1) }\end{array}$ & {$[35,36,54]$} \\
\hline & PT-VWD & $\mathrm{AD}$ & mild/moderate & $\begin{array}{l}\text { Macrothrombocytopenia; } \\
\text { increased response to ristocetin } \\
\text { and decreased VWF-ristocetin } \\
\text { cofactor activity (VWF:RCo) } \\
\text { Mixing tests discriminate the } \\
\text { plasmatic (VWD type2B) from } \\
\text { platelet (PT-VWD) origin of } \\
\text { hyperreactivity to ristocetin }\end{array}$ & {$[36,76,77]$} \\
\hline & $\begin{array}{l}\text { PRKACG-related } \\
\text { thrombocytopenia }\end{array}$ & $\mathrm{AR}$ & severe & $\begin{array}{l}\text { Macrothrombocytopenia; } \\
\text { defective platelet } \alpha_{\mathrm{IIb}} \beta_{3} \\
\text { activation and P-selectin } \\
\text { exposure in response to TRAP6; } \\
\text { defective } \mathrm{Ca}^{2+} \text { mobilization in } \\
\text { response to thrombin }\end{array}$ & {$[40]$} \\
\hline & $\begin{array}{l}\text { THPO-related } \\
\text { thrombocytopenia }\end{array}$ & $\mathrm{AD}$ & mild & $\begin{array}{l}\text { Normal or slightly increased } \\
\text { platelet size }\end{array}$ & [26] \\
\hline & $\begin{array}{l}\text { TRPM7-related } \\
\text { thrombocytopenia }\end{array}$ & $\mathrm{AD}$ & mild/moderate & $\begin{array}{l}\text { Macrothrombocytopenia; } \\
\text { aberrant distribution of } \\
\text { granules }\end{array}$ & [42] \\
\hline & $\begin{array}{c}\text { Tropomyosin } 4 \\
\text { (TPM)-related } \\
\text { thrombocytopenia }\end{array}$ & $\mathrm{AD}$ & mild & Macrothrombocytopenia & [43] \\
\hline & $\begin{array}{l}\text { TUBB-1-related } \\
\text { thrombocytopenia }\end{array}$ & $\mathrm{AD}$ & mild & $\begin{array}{l}\text { Macrothrombocytopenia; } \\
\text { platelet anisocytosis }\end{array}$ & [44] \\
\hline & $\begin{array}{l}\text { SLFN14-related } \\
\text { thrombocytopenia }\end{array}$ & $\mathrm{AD}$ & mild/moderate & $\begin{array}{c}\text { Macrothrombocytopenia; } \\
\delta \text {-granule deficiency with } \\
\text { decreased ATP secretion in } \\
\text { response to ADP, collagen and } \\
\text { TRAP-6 }\end{array}$ & [49] \\
\hline \multirow{4}{*}{$\begin{array}{l}\text { Forms pre- } \\
\text { disposing } \\
\text { to } \\
\text { additional } \\
\text { diseases }\end{array}$} & $\begin{array}{l}\text { ANKRD26-related } \\
\text { thrombocytopenia }\end{array}$ & $\mathrm{AD}$ & mild/moderate & $\begin{array}{l}\text { Reduced } \alpha \text {-granules in some } \\
\text { patients }\end{array}$ & [13] \\
\hline & $\begin{array}{l}\text { Congenital amegakaryocytic } \\
\text { thrombocytopenia (CAMT) }\end{array}$ & $\mathrm{AR}$ & severe & Elevated serum levels of TPO & [22] \\
\hline & $\begin{array}{l}\text { DIAPH1-related } \\
\text { thrombocytopenia }\end{array}$ & $\mathrm{AD}$ & mild/severe & Macrothrombocytopenia & {$[31]$} \\
\hline & $\begin{array}{l}\text { ETV6-related } \\
\text { thrombocytopenia }\end{array}$ & $\mathrm{AD}$ & mild/moderate & $\begin{array}{l}\text { Decreased ability of platelets to } \\
\text { spread on fibrinogen covered } \\
\text { surfaces; abnormal clot } \\
\text { retraction }\end{array}$ & [14] \\
\hline
\end{tabular}


Table 3. Cont.

\begin{tabular}{|c|c|c|c|c|c|}
\hline Form & Disease & Inheritance & $\begin{array}{l}\text { Degree of Throm- } \\
\text { bocytopenia }\end{array}$ & Key Laboratory Features & References \\
\hline & $\begin{array}{l}\text { Familial platelet disorder } \\
\text { with predisposition to } \\
\text { hematological malignancies } \\
\text { (FPD/AML) }\end{array}$ & $\mathrm{AD}$ & moderate & $\begin{array}{l}\text { Abnormal aggregation in } \\
\text { response to multiple agonists; } \delta \\
\text { (occasionally } \alpha \text { )-granule } \\
\text { deficiency }\end{array}$ & [25] \\
\hline & MYH9-related disease & $\mathrm{AD}$ & mild/severe & $\begin{array}{l}\text { Macrothrombocytopenia; } \\
\text { Döhl-like body cytoplasmic } \\
\text { leukocyte inclusions }\end{array}$ & [38] \\
\hline & $\begin{array}{l}\text { Thrombocytopenia } \\
\text { associated with } \\
\text { sitosterolemia }\end{array}$ & & moderate/severe & $\begin{array}{l}\text { Macrothrombocytopenia; } \\
\text { hyperactivatable platelets with } \\
\text { constitutive binding of } \\
\text { fibrinogen to } \alpha_{\mathrm{IIb}} \beta_{3} \text { integrin; } \\
\text { shedding of GPIb } \alpha \text {; impaired } \\
\text { platelet adhesion to von } \\
\text { Willebrand factor }\end{array}$ & [46] \\
\hline
\end{tabular}

The platelet aggregation pattern may be typical of some ITs like biallelic BSS, associated with no response to ristocetin but normal aggregation to all other agonists, or PT-VWD, with increased response to ristocetin.

Measurement of platelet glycoproteins by flow cytometry, using a well-defined set of antibodies, is the gold standard for the diagnosis of biallelic and monoallelic BSS, ITGA2B/ITGB3-RT and GFI1B-RT.

The measurement of platelet granule content and secretion can reveal alterations, e.g., in WAS and thrombocytopenia with absent radii (TAR) a reduced number of densegranules has been reported, GPS is characterized by absent or reduced $\alpha$-granules [78], Paris-Trousseau (PTS) and Jacobsen syndromes show abnormally large $\alpha$-granules, while patients with FLNA-RT show some platelets having a reduced number of $\alpha$-granules and others with enlarged $\alpha$-granules [15,79].

Other structural abnormalities, like membranous inclusions, platelet organelle abnormalities, endoplasmic reticulum (ER)-derived inclusion bodies or particulate cytoplasmic structures with immunoreactivity for polyubiquitinated proteins and proteasome (PaCSs) [32], can be detected by electron microscopy in platelets from some specific ITs (Table 3) [18].

Additional tests may be required for complex cases, including the measurement of platelet phosphatidylserine expression, by flow cytometry, to detect enhanced procoagulant activity (Stormorken syndrome), spreading or adhesion assays to detect increased spreading in FLNA-RT, or western blotting for detection of specific proteins usually absent from platelets (e.g., MYH10 in FPD/AML and FLI1-RT).

Some additional non platelet-related laboratory tests may complement physical examination in the search for syndromic manifestations, like urinalysis, to detect proteinuria as the first sign of renal impairment in MYH9-RD, or the liver enzymes, which are elevated in approximately $50 \%$ of patients with this disease [80].

\subsection{Genetic Analysis}

While genotyping has mainly been used as a confirmatory test in the past, it is now playing an increasing role in the initial diagnostic approach to IT.

Until a few years ago, in fact, when the inherited nature of thrombocytopenia was suspected, a series of laboratory tests (e.g., flow cytometry for platelet surface GPs, examination of peripheral blood smear and immunofluorescence assay for MYH9 protein aggregates in neutrophils, platelet aggregometry) were performed to orient towards the candidate gene/genes to be sequenced by Sanger sequencing [66]. The application of high throughput sequencing (HTS) techniques to platelet disorders has allowed for the discovery of several novel genes associated with IT in a few years and has opened the 
possibility of approaching IT diagnosis by a single-step strategy. In fact, the simultaneous screening of several genes by targeted sequencing platforms, whole exome sequencing (WES) or whole genome sequencing (WGS) has been shown to provide diagnosis in $30 \%$ to $50 \%$ of patients with suspected IT [81-83]. Indeed, HTS is being proposed as a first line diagnostic investigation by an increasing number of authors [82-85]. However, the interpretation of genetic variants is challenging and requires a careful expert team evaluation in light of a well characterized patient phenotype [84] and when new variants in diagnostic-grade (TIER1) genes are found by targeted sequencing, WES or WGS or new genes are identified by WES or WGS it is essential that rigorous guidelines (i.e., the ACMG guidelines [86]) are applied to confirm their pathogenicity [84]. No guidelines are available yet regarding which suspected IT patients should undergo genetic testing. Some ITs with pathognonomic laboratory or clinical features, such as BSS, TAR, GATA1-RD, ATRUS, Stormorken syndrome and WAS, can be clearly diagnosed without the need of genetic testing. For other ITs, for which a strong genotype-phenotype correlation has been described, e.g., MYH9-RD, genotyping may be advisable for prognostic evaluation and possible preventive intervention. Other forms that do not have any specific diagnostic, clinical or laboratory features would require genetic testing for definite diagnosis. However, for some of these, e.g., ACTN1-RT or TUBB1-RT, a genetic diagnosis does not have any significant impact on patient management, while for others it may inform patients monitoring and treatment. Among these there are thrombocytopenias with normal platelet volume, including forms like FPD/AML, ANKRD26-RT and ETV6-RT which are predisposed to hematological malignancies (Figure 2). There are ethical implications of detecting variants in these genes and other unexpected genetic defects, such as a carrier status of a recessive gene. It is thus recommended to strictly follow an informed consent protocol ensuring that patients comprehend the possible implications of unsolicited genetic findings [85].

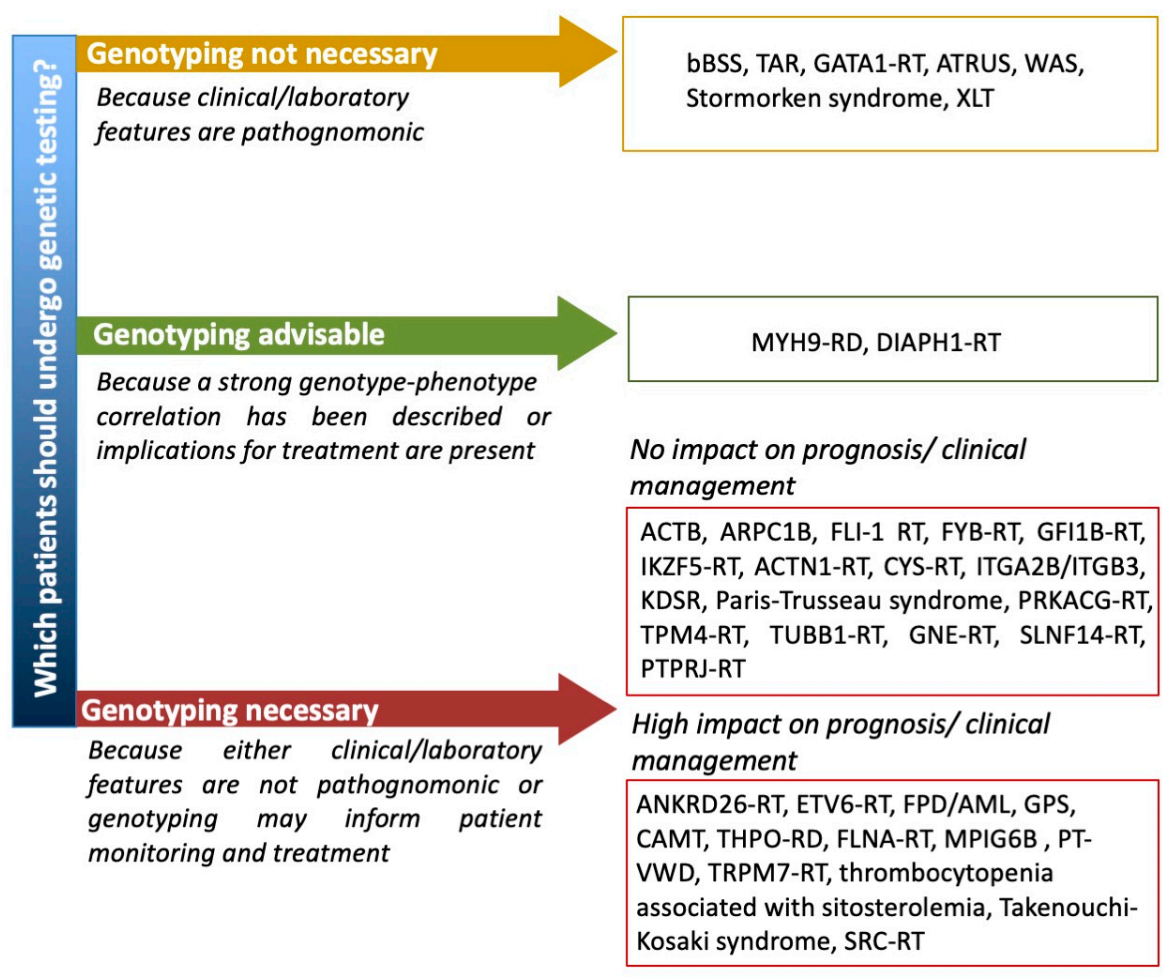

Figure 2. Proposal of a flow chart guiding the use of genetic testing for patients with suspected IT. ACTB = Baraitser-Winter syndrome 1 with macrothrombocytopenia, ARPC1B = Platelet abnormalities with eosinophilia and immune-mediated inflammatory disease, ATRUS = amegakaryocytic thrombocytopenia with radio-ulnar synostosis, bBSS = biallelic Bernard Soulier syndrome, CAMT = congenital amegakaryocytic thrombocytopenia, MPIG6B = thrombocytopenia, anemia and myelofibrosis, PT-VWD = platelet-type von Willebrand disease, RD = related disorder, RT = related thrombocytopenia, $\mathrm{TAR}=$ thrombocytopenia with absent radii, $\mathrm{XLT}=\mathrm{X}$-linked thrombocytopenia, $\mathrm{WAS}=$ Wiskott-Aldrich syndrome. 
In summary, the optimal diagnostic approach to ITs is still being debated and a combination of clinical/traditional laboratory approach with advanced gene sequencing techniques may provide the highest rate of diagnostic success [69], and the best patient management.

\subsection{Undefined Aspects and Possible Future Research Lines}

A consensus on the classification of ITs has not been reached yet, but it would be highly advisable to avoid, for example, ambiguity on disease nomenclature.

A guidance flow chart about which suspected IT patients should undergo genetic testing is not yet available and the generation of consensus documents promoted by the relevant international scientific societies (ISTH, EHA, ASH) is highly warranted.

Moreover, development of guidelines on informed consent documents, reporting of new variants in variant databases to improve variant classification, development of user-friendly interpretation softwares of HTS results, promotion of research for discovery of new genes causing IT and development of advanced cell-based models to study platelet formation and function are valuable future perspectives.

\section{Bleeding and Other Manifestations}

Bleeding manifestations of IT are of variable severity, ranging from severe in rare cases, recognized within a few weeks from birth, to mild or absent [87]. They are characterized by mucocutaneous symptoms, including epistaxis, easy bruising, petechiae, prolonged bleeding from cuts, gum bleeding, hematuria and menorrhagia in women but also by excessive bleeding after surgery or post-partum hemorrhages [5,88,89].

A recent large systematic investigation on the diagnostic utility of the ISTH bleeding assessment tool (ISTH-BAT) in patients with inherited platelet disorders showed that the bleeding history of most patients with IT without associated platelet function defect is not severe, with a median ISTH-BAT bleeding score (BS) of 2, quite comparable to that of healthy subjects [65]. Usually, the bleeding risk is negligible in subjects with more than $100 \times 10^{9}$ platelets/L, mild/moderate in subjects with $50-100 \times 10^{9}$ platelets/L (risk of hemorrhages on the occasion of major hemostatic challenges) and significant when platelets are lower than $50 \times 10^{9} / \mathrm{L}$, especially when below $20 \times 10^{9} / \mathrm{L}$ [90].

On the other hand, in ITs associated with defective platelet function (Table 2) the bleeding history shows a moderate/severe hemorrhagic tendency, with high BS, like in patients with biallelic-BSS (median BS 8.5), GPS (median BS 12) and ITGA2B/ITGB3-RT (median BS 8) [65]. For other rare and/or underdiagnosed ITs, such as PT-VWD, GATA-1 RD or CYCS-RT $[65,91]$, the hemorrhagic risk is still poorly defined.

Pregnancy and delivery are a major concern for patients with ITs because both the mother and the affected newborn may be at risk of bleeding. A large multicentric, retrospective study evaluated 339 pregnancies in 181 women with 13 different forms of IT and showed that neither the degree of thrombocytopenia nor the severity of the bleeding tendency worsened during pregnancy and that, in general, the course of pregnancy did not differ from that of healthy subjects. However, post-partum hemorrhage was more frequent in ITs, ranging from $6.8 \%$ to $14.2 \%$ vs. $3 \%$ to $7 \%$ in control women, with the degree of thrombocytopenia (platelet count at delivery below $50 \times 10^{9} / \mathrm{L}$ ) and previous history of severe bleeding being predictive of delivery-associated hemorrhage. Patients with MYH9RD, ANKRD26-RT, biallelic and monoallelic BSS, FPD/AML, GPS and PT-VWD showed the highest frequency of post-partum bleeding [72].

Delivery-related neonatal hemorrhages were instead quite rare $(4.5 \%$ of affected newborns), although two fatal cerebral hemorrhages out of 278 childbirths were reported [72]. Recently, pregnancy and delivery in a woman with DIAPH1-RD were reported with no changes in platelet count and no bleeding at delivery or postpartum [92].

Another feared complication in patients with IT is excessive bleeding after surgery and a multicentric, retrospective worldwide study recently assessed the bleeding complications of surgery, the preventive and therapeutic approaches adopted and their efficacy in patients with inherited platelet disorders. The study showed that the frequency of surgical bleeding 
was higher in patients than in healthy controls $(19.7 \%$ vs. $1.4 \%-6 \%)$, however in patients with IT and normal platelet function bleeding incidence was relatively low (13.4\%) with $68 \times 10^{9} /$ L platelets being the threshold below which bleeding rate increased significantly, while in IT patients with associated platelet dysfunction post-surgical hemorrhage was frequent, in particular in those with bBSS (44.4\%), FPD/AML (30.8\%), GPS (23.5\%) and ITGA2B/ITGB3-RT (22.7\%) [93].

Although bleeding is conventionally considered the main clinical complication in patients with IT, some ITs have the propensity to develop other disorders, including hematological malignancies or bone marrow aplasia [82,94], while others have associated syndromic manifestations, like skeletal malformations, liver and kidney malfunction and deafness. For instance, $40 \%$ of subjects with FDP/AML develop acute myelogenous leukemia (AML) or myelodysplastic syndromes (MDS) with a median age of onset of 33 years old, $8 \%$ of subjects with ANRD26-RT develop MDS or AML and $25 \%$ of subjects with ETV6-RT develop hematologic malignancies [95]. Moreover, genotype-phenotype correlation studies in MYH9-RD patients have reported that variants in the head domain of MYH9 are associated with more severe thrombocytopenia and a higher frequency and/or rapid progression of deafness and nephropathy than variants in the tail domain, with the amino acid substitution p.Arg702Cys being associated with the most severe phenotype [96,97].

\section{Prophylaxis and Treatment Options}

The management of patients with IT should aim to prevent bleeding and treat hemorrhages but also to arrest or slowdown the development of systemic complications or treat them $[98,99]$.

\subsection{General Prophylactic Measures}

Patients should avoid drugs interfering with platelet function, such as aspirin and non-steroidal anti-inflammatory drugs, perform accurate dental hygiene, and, for the most serious forms, avoid contact sports. Given the possibility that these patients will be exposed to blood transfusions during their life, it is important that they receive immunization against hepatitis A and B and annual liver function tests [99]. Correction of iron deficiency is often required, especially in children and young women [100]. Prenatal diagnosis can be carried out for the most serious forms when the familial mutation is known. Moreover, mutational screening of potential sibling donors is highly warranted for patients with risk of developing hematological malignancy who may therefore require future hematopoietic stem cells transplantation, such as in FPD/AML, ANKRD26-RT and ETV6-RD [101]. Screening for renal failure and cataract in MYH9-RT, for deafness in MYH9$\mathrm{RD}$ and DIAPH1-RT, and for myelofibrosis and immune disorders in GPS is warranted. In fact, immune derangement in GPS has been recently shown, with more than one-half of patients having detectable autoantibodies and one-quarter clinically evident autoimmune disorders, including Hashimoto's thyroiditis, rheumatoid arthritis, alopecia, discoid lupus erythematosus, vitiligo and atypical autoimmune lymphoproliferative syndrome usually associated with cytopenia of at least one leukocyte type [79].

\subsection{Female Hormones}

Menarche, particularly in patients with BSS, may be associated with excessive bleeding [89]. This can be treated by intravenous (IV) infusion of high-dose conjugated estrogen for 24-48 h followed by high doses of oral estrogen-progestin. Thereafter, a combined oral contraceptive can be given continuously for 2-3 months. In women in whom antifibrinolytic agents fail to decrease menorrhagia, long term oral contraceptives can be given, especially when iron deficiency anemia develops [102]. 


\subsection{Local Hemostatic Measures}

Electrocautery and nasal packing are used for epistaxis, while compression, suturing, and application of gelatin sponges or gauzes soaked in tranexamic acid for accidental or surgical wound bleedings. Mouthwashes with tranexamic acid, application of fibrin sealant or absorbable gelatin sponge with topical thrombin may be useful for gingival bleeding. Non-conventional hemostatic agents, such as Ankaferd Blood Stopper has been used in some patients in cases of inefficacy of the classical measures [103]. A relatively new method proposed for the acceleration of wound healing are platelet-rich clots, due to the release of several growth factors from platelets, although it still requires standardization and validation [104]. Autologous platelet-rich clots were used with success, in conjunction with tranexamic acid given orally, to prevent bleeding during dental extraction for a patient with PT-VWD [105].

\subsection{Platelet Transfusions}

Given the risk of alloimmunization, allergic reactions and infections, platelet transfusion should be used only for severe bleeding which cannot be managed by local measures. Moreover, to prevent HLA-alloimmunization and reactions, HLA-matched and leukodepleted concentrates should be used. In case alloimmune antibodies develop, e.g., against $\mathrm{GPIb} / \mathrm{IX} / \mathrm{V}$ in BSS, immunosuppression and/or plasmapheresis can restore platelet transfusion efficacy.

Of note, the use of pre-operative antihemorrhagic prophylaxis was associated with a lower bleeding frequency in patients with inherited platelet function disorders but not with IT, indeed in the latter group bleeding was reported in $12.7 \%$ of the procedures carried out without preparation and in $14.9 \%$ of the procedures carried out with pre-operative antihemorrhagic prophylaxis. On the other hand, the choice of the preventive measures did not appear to be always appropriate, in fact platelet transfusions, the most frequently used prophylactic treatment, revealed to be poorly effective, suggesting that either other treatments are required, or that the way platelet transfusions are employed (amount, type, timing) is inappropriate [93].

\subsection{Antifibrinolytic Agents}

Antifibrinolytic agents (AF), such as $\varepsilon$-aminocaproic acid or tranexamic acid, used as single drugs or in association with other treatments, have been shown to be useful for covering minor surgery in patients with IT or in arresting epistaxis, gingival bleeding or menorrhagia $[93,96]$. However, no specific prospective clinical study on the effectiveness of these drugs in ITs has been performed, and should therefore be considered empirical. AFs are usually contraindicated for hematuria given the risk of clot formation in the urinary tract [106], however exceptions have been reported [107] and the evidence of AF-associated clot risk is weak and based on old, uncontrolled data [108].

\subsection{Desmopressin}

Desmopressin (1-deamino-8-D-arginine vasopressin, DDAVP) is an approved treatment for mild hemophilia A and type 1 von Willebrand disease, but is also used for congenital and acquired defects of platelet function because it has a general prohemostatic effect and it enhances the procoagulant activity of platelets [109]. Clinical studies on the efficacy of DDAVP in ITs are lacking, however DDAVP has been shown to successfully cover minor surgery in some IT patients, such as MYH9-RD, ANKRD26-RT and Paris-Trousseau syndrome $[92,110,111]$. In elderly patients and in patients with a history of cardiovascular disease DDAVP should be used with caution for increased risk of thrombosis as well as in infants below two years of age for the risk of fluid retention.

\subsection{VWF-Rich Concentrates}

VWF-rich concentrates are the most effective treatments, together with platelet transfusions, for major bleeding in PT-VWD. The dose of VWF-rich concentrates depends on the 
level of VWF:RCo and can be adjusted on demand. A target of 50-60\% VWF:RCo/VWF activity in major surgery and $30-50 \%$ in minor ones is advisable (typically from 10 to $30 \mathrm{U} / \mathrm{kg}$ at $12 \mathrm{~h}$ intervals) [76].

\subsection{Activated Recombinant Factor VIIa (rFVIIa)}

rFVIIa is currently approved for treating hemophiliacs with inhibitors and patients with Glanzmann thrombasthenia [112]. In the setting of ITs, rFVIIa has been successfully used as prophylactic measure for invasive procedures in biallelic BSS, PT-VWD and TAR [113]. Severe adverse events, including myocardial infarction, ischemic stroke and venous thromboembolism have occasionally been reported.

\subsection{Eltrombopag}

Eltrombopag is an oral TPO-mimetic indicated for chronic refractory immune thrombocytopenic purpura (ITP), severe aplastic anemia and HCV-related thrombocytopenia. It has been shown to be effective in increasing transiently the platelet count in ITs. In two phase 2 clinical trials, eltrombopag given for three to six weeks was shown to be safe and effective in increasing platelet count and reducing bleeding symptoms in 10 out of 11 patients with MYH9-RD [114] and in 21 out of 23 patients with MYH9-RD, ANKRD26-RD, XLT/WAS, monoallelic BSS and ITGA2B/ITGB3-RT [115].

Long-term eltrombopag (i.e., eltrombopag administration for more than six months) to maintain stable safe platelet counts has been used in eight patients with WAS /XLT and severe thrombocytopenia. Five responded well, obtaining a stable increase of platelet count and reduction of spontaneous bleeding without major adverse events [116]. However, potential side effects of a life-long treatment (such as bone marrow fibrosis) need to be carefully considered.

Moreover, eltrombopag has been successfully used for preparation to surgery in patients with MYH9-RD and severe thrombocytopenia [117-119]. Recently, treatment with eltrombopag allowed to attain a safe and stable platelet count to allow chemotherapy in a patient with MHY9-related disorder and pancreatic cancer and permitted to perform endoscopic placement of a biliary stent with no bleeding complications [120].

\subsection{Hematopoietic Stem Cell Transplantation (HSCT) and Gene Therapy}

HSCT has become the treatment of choice for patients with WAS, with a 5-year overall survival rate of $90 \%-100 \%$ [121], and with CAMT, with a long-term survival rate of $80 \%$ [122], patients who have, without this treatment, a life expectancy of 15 years and a few months, respectively [122,123]. Bone marrow transplantation from HLA-identical donors has also been used with success in some cases of BSS with severe hemorrhage and/or alloantibodies [124] and in patients with XLT [125]. However, a careful evaluation of the risk-benefit ratio must always be made.

In humans, the feasibility of gene therapy has been proven in patients with WAS with sustained clinical benefit, normalization of platelet volume and partial increase of platelet count [126-128]. Research is ongoing for gene therapy of BSS in a mouse model [129] and of CAMT in induced pluripotent stem cells [22].

\subsection{Splenectomy}

Splenectomy is effective in patients with WAS/XLT, increasing platelet count and reducing the incidence of serious bleedings, however it significantly increases the incidence of subsequent severe infectious events and it does not increase overall survival [130]. Thus, the risk-benefit balance should be carefully weighed in each patient and vaccination and anti-infective prophylaxis should always be performed [131].

\section{Conclusions}

Thrombocytopenia is a frequent condition for the internist and the hematologist, and its differential diagnosis is frequently complex and cumbersome. Among the various 
possible etiologies of thrombocytopenias, inherited forms should be promptly recognized to avoid unnecessary, and frequently potentially dangerous treatments, and to allow the precise formulation of prognostic expectations.

Recent advances in the understanding of the pathogenic mechanisms of gene variants provoking thrombocytopenia, of the phenotypic manifestations of specific IT-associated gene variants, in the diagnostic approach to ITs and in the therapeutic opportunities have yielded improvements in patient care and deeper insight into the physiologic regulation of circulating platelet levels.

Future challenges are the identification of the genetic cause of the remaining 50\% of so far unclassified ITs, the unraveling of the precise phenotypic features of several IT forms, the understanding of the role in megakaryopoiesis of some mutated genes found to be associated with ITs, the development of new therapeutic approaches and of the best use of those currently available and the identification of sophisticated in vitro models of megakaryopoiesis to allow better modelling studies with patient derived MK or induced pluripotent stem cells.

Only continued research and the creation of a wide international collaborative network among investigators and clinicians in the field will allow to respond to these.

Author Contributions: E.F. and L.B. prepared the original draft; P.G. supervised the manuscript preparation and reviewed the manuscript. All authors have read and agreed to the published version of the manuscript.

Funding: This work was supported by a fellowship by Fondazione Umberto Veronesi to LB and EF.

Conflicts of Interest: The authors declare no conflict of interest.

\section{References}

1. Balduini, C.L.; Pecci, A.; Noris, P. Inherited thrombocytopenias: The evolving spectrum. Hamostaseologie 2012, 32, 259-270. [PubMed]

2. Oved, J.H.; Lambert, M.P.; Kowalska, M.A.; Poncz, M.; Karczewski, K.J. Population based frequency of naturally occurring loss-of-function variants in genes associated with platelet disorders. J. Thromb. Haemost. 2021, 19, 248-254. [CrossRef] [PubMed]

3. Bury, L.; Falcinelli, E.; Gresele, P. Qualitative Disorders of Platelet Function. In Wintrobe's Clinical Hematology, 14th ed.; Greer, J.P., Appelbaum, F., Arber, D.A., Dispenzieri, A., Fehniger, T., Glader, B., List, A.F., Eds.; Lippincott Williams \& Wilkins: Philadelphia, PA, USA, 2018; pp. 3482-3527.

4. Pecci, A.; Balduini, C.L. Inherited thrombocytopenias: An updated guide for clinicians. Blood Rev. 2020, 100784. [CrossRef] [PubMed]

5. Johnson, B.; Doak, R.; Allsup, D.; Astwood, E.; Evans, G.; Grimley, C.; James, B.; Myers, B.; Stokley, S.; Thachil, J.; et al. A comprehensive targeted next-generation sequencing panel for genetic diagnosis of patients with suspected inherited thrombocytopenia. Res. Pract. Thromb. Haemost. 2018, 2, 640-652. [CrossRef]

6. Machlus, K.R.; Italiano, J.E. The incredible journey: From megakaryocyte development to platelet formation. J. Cell Biol. 2013, 201, 785-796. [CrossRef]

7. Nishimura, S.; Nagasaki, M.; Kunishima, S.; Sawaguchi, A.; Sakata, A.; Sakaguchi, H.; Ohmori, T.; Manabe, I.; Italiano, J.E.; Ryu, T.; et al. IL-1 $\alpha$ induces thrombopoiesis through megakaryocyte rupture in response to acute platelet needs. J. Cell Biol. 2015, 209, 453-466. [CrossRef]

8. Potts, K.S.; Farley, A.; Dawson, C.A.; Rimes, J.S.; Biben, C.; De Graaf, C.A.; Potts, M.A.; Stonehouse, O.J.; Carmagnac, A.; Gangatirkar, P.; et al. Membrane budding is a major mechanism of in vivo platelet biogenesis. J. Exp. Med. 2020, 217. [CrossRef]

9. Looney, M.R. The incomparable platelet: Holy alveoli. Blood 2018, 132, 1088-1089. [CrossRef]

10. AlMazni, I.; Stapley, R.; Morgan, N.V. Inherited Thrombocytopenia: Update on Genes and Genetic Variants Which may be Associated with Bleeding. Front. Cardiovasc. Med. 2019, 6, 80. [CrossRef]

11. Nurden, A.T.; Nurden, P. Inherited thrombocytopenias: History, advances and perspectives. Haematologica 2020, 105, 2004-2019. [CrossRef]

12. Balduini, C.L.; Melazzini, F.; Pecci, A. Inherited thrombocytopenias-recent advances in clinical and molecular aspects. Platelets 2017, 28, 3-13. [CrossRef] [PubMed]

13. Bluteau, D.; Balduini, A.; Balayn, N.; Currao, M.; Nurden, P.; Deswarte, C.; Leverger, G.; Noris, P.; Perrotta, S.; Solary, E.; et al. Thrombocytopenia associated mutations in the ANKRD26 regulatory region induce MAPK hyperactivation. J. Clin. Investig. 2014, 124, 580-591. [CrossRef] [PubMed]

14. Noetzli, L.; Lo, R.W.; Lee-Sherick, A.B.; Callaghan, M.; Noris, P.; Savoia, A.; Rajpurkar, M.; Jones, K.; Gowan, K.; Balduini, C.L.; et al. Germline mutations in ETV6 are associated with thrombocytopenia, red cell macrocytosis and predisposition to lymphoblastic leukemia. Nat. Genet. 2015, 47, 535-553. [CrossRef] [PubMed] 
15. Nurden, P.; Debili, N.; Coupry, I.; Bryckaert, M.; Youlyouz-Marfak, I.; Sole', G.; Pons, A.C.; Berrou, E.; Adam, F.; Kauskot, A.; et al. Thrombocytopenia resulting from mutations in filamin A can be expressed as an isolated syndrome. Blood 2011, 118, 5928-5937. [CrossRef] [PubMed]

16. Levin, C.; Koren, A.; Pretorius, E.; Rosenberg, N.; Shenkman, B.; Hauschner, H.; Zalman, L.; Khayat, M.; Salama, I.; Elpeleg, O.; et al. Deleterious mutation in the FYB gene is associated with congenital autosomal recessive small-platelet thrombocytopenia. J. Thromb. Haemost. 2015, 13, 1285-1292. [CrossRef]

17. Songdej, N.; Rao, A.K. Hematopoietic transcription factor mutations and inherited platelet dysfunction. F1000Prime Rep. 2015, 7, 66. [CrossRef]

18. Gresele, P. Subcommittee on Platelet Physiology of the International Society on Thrombosis and Hemostasis. Diagnosis of inherited platelet function disorders: Guidance from the SSC of the ISTH. J. Thromb. Haemost. 2015, 13, 314-322. [CrossRef]

19. Horvat-Switzer, R.D.; Thompson, A.A. HOXA11 mutation in amegakaryocytic thrombocytopenia with radio-ulnar synostosis syndrome inhibits megakaryocytic differentiation in vitro. Blood Cells Mol. Dis. 2006, 37, 55-63. [CrossRef]

20. Germeshausen, M.; Ancliff, P.; Estrada, J.; Metzler, M.; Ponstingl, E.; Rütschle, H.; Schwabe, D.; Scott, R.H.; Unal, S.; Wawer, A.; et al. MECOM-associated syndrome: A heterogeneous inherited bone marrow failure syndrome with amegakaryocytic thrombocytopenia. Blood Adv. 2018, 2, 586-596. [CrossRef]

21. Lentaigne, C.; Greene, D.; Sivapalaratnam, S.; Favier, R.; Seyres, D.; Thys, C.; Grassi, L.; Mangles, S.; Sibson, K.; Stubbs, M.J.; et al. Germline mutations in the transcription factor IKZF5 cause thrombocytopenia. Blood 2019, 134, 2070-2081. [CrossRef]

22. Hirata, S.; Takayama, N.; Jono-Ohnishi, R.; Endo, H.; Nakamura, S.; Dohda, T.; Nishi, M.; Hamazaki, Y.; Ishii, E.; Kaneko, S.; et al. Congenital amegakaryocytic thrombocytopenia iPS cells exhibit defective MPL-mediated signaling. J. Clin. Investig. 2013, 123, 3802-3814. [CrossRef] [PubMed]

23. Pluthero, F.G.; Di Paola, J.; Carcao, M.D.; Kahr, W.H.A. NBEAL2 mutations and bleeding in patients with gray platelet syndrome. Platelets 2018, 29, 632-635. [CrossRef] [PubMed]

24. Albers, C.A.; Newbury-Ecob, R.; Ouwehand, W.H.; Ghevaert, C. New insights into the genetic basis of TAR (thrombocytopeniaabsent radii) syndrome. Curr. Opin. Genet. Dev. 2013, 23, 316-323. [CrossRef] [PubMed]

25. Sakurai, M.; Kunimoto, H.; Watanabe, N.; Fukuchi, Y.; Yuasa, S.; Yamazaki, S.; Nishimura, T.; Sadahira, K.; Fukuda, K.; Okano, H.; et al. Impaired hematopoietic differentiation of RUNX1-mutated induced pluripotent stem cells derived from FPD/AML patients. Leukemia 2014, 28, 2344-2354. [CrossRef]

26. Dasouki, M.J.; Rafi, S.K.; Olm-Shipman, A.J.; Wilson, N.R.; Abhyankar, S.; Ganter, B.; Furness, L.M.; Fang, J.; Calado, R.T.; Saadi, I. Exome sequencing reveals a thrombopoietin ligand mutation in a Micronesian family with autosomal recessive aplastic anemia. Blood 2013, 122, 3440-3449. [CrossRef]

27. Latham, S.L.; Ehmke, N.; Reinke, P.Y.A.; Taft, M.H.; Eicke, D.; Reindl, T.; Stenzel, W.; Lyons, M.J.; Friez, M.J.; Lee, J.A.; et al. Variants in exons 5 and 6 of ACTB cause syndromic thrombocytopenia. Nat. Commun. 2018, 9, 4250. [CrossRef]

28. Kunishima, S.; Okuno, Y.; Yoshida, K.; Shiraishi, Y.; Sanada, M.; Muramatsu, H.; Chiba, K.; Tanaka, H.; Miyazaki, K.; Sakai, M.; et al. ACTN1 mutations cause congenital macrothrombocytopenia. Am. J. Hum. Genet. 2013, 92, 431-438. [CrossRef]

29. Kahr, W.H.; Pluthero, F.G.; Elkadri, A.; Warner, N.; Drobac, M.; Chen, C.H.; Lo, R.W.; Li, L.; Li, R.; Li, Q.; et al. Loss of the Arp2/3 complex component ARPC1B causes platelet abnormalities and predisposes to inflammatory disease. Nat. Commun. 2017, 8 , 14816. [CrossRef]

30. Morison, I.M.; Cramer Borde, E.M.; Cheesman, E.J.; Cheong, P.L.; Holyoake, A.J.; Fichelson, S.; Weeks, R.J.; Lo, A.; Davies, S.M.; Wilbanks, S.M.; et al. A mutation of human cytochrome c enhances the intrinsic apoptotic pathway but causes only thrombocytopenia. Nat. Genet. 2008, 40, 387-389. [CrossRef]

31. Stritt, S.; Nurden, P.; Turro, E.; Greene, D.; Jansen, S.B.; Westbury, S.K.; Petersen, R.; Astle, W.J.; Marlin, S.; Bariana, T.K.; et al. A gain-of-function variant in DIAPH1 causes dominant macrothrombocytopenia and hearing loss. Blood 2016, 127, 2903-2914. [CrossRef]

32. Necchi, V.; Balduini, A.; Noris, P.; Barozzi, S.; Sommi, P.; di Buduo, C.; Balduini, C.L.; Solcia, E.; Pecci, A. Ubiqui-tin/proteasomerich particulate cytoplasmic structures (PaCSs) in the platelets and megakaryocytes of ANKRD26-related thrombo-cytopenia. Thromb. Haemost. 2013, 109, 263-271. [CrossRef] [PubMed]

33. Balduini, A.; Malara, A.; Balduini, C.L.; Noris, P. Megakaryocytes derived from patients with the classical form of Bernard-Soulier syndrome show no ability to extend proplatelets in vitro. Platelets 2011, 22, 308-311. [CrossRef] [PubMed]

34. Bury, L.; Malara, A.; Momi, S.; Petito, E.; Balduini, A.; Gresele, P. Mechanisms of thrombocytopenia in platelet-type von Willebrand disease. Haematologica 2019, 104, 1473-1481. [CrossRef] [PubMed]

35. Bury, L.; Falcinelli, E.; Chiasserini, D.; Springer, T.A.; Italiano, J.E., Jr.; Gresele, P. Cytoskeletal perturbation leads to platelet dysfunction and thrombocytopenia in Glanzmann variants. Haematologica 2016, 101, 46-56. [CrossRef]

36. Bury, L.; Malara, A.; Gresele, P.; Balduini, A. Outside-in signalling generated by a constitutively activated integrin $\alpha \mathrm{IIb} \beta 3$ impairs proplatelet formation in human megakaryocytes. PLoS ONE 2012, 7, e34449. [CrossRef]

37. Bariana, T.K.; Labarque, V.; Heremans, J.; Thys, C.; De Reys, M.; Greene, D.; Jenkins, B.; Grassi, L.; Seyres, D.; Burden, F.; et al. Sphingolipid dysregulation due to lack of functional KDSR impairs proplatelet formation causing thrombocytopenia. Haematologica 2019, 104, 1036-1045. [CrossRef]

38. Pecci, A.; Malara, A.; Badalucco, S.; Bozzi, V.; Torti, M.; Balduini, C.L.; Balduini, A. Megakaryocytes of patients with MYH9-related thrombocytopenia present an altered proplatelet formation. Thromb. Haemost. 2009, 102, 90-96. 
39. Hofmann, I.; Geer, M.J.; Vögtle, T.; Crispin, A.; Campagna, D.R.; Barr, A.; Calicchio, M.L.; Heising, S.; van Geffen, J.P.; Kuijpers, M.J.E.; et al. Congenital macrothrombocytopenia with focal myelofibrosis due to mutations in human G6b-B is rescued in humanized mice. Blood 2018, 132, 1399-1412. [CrossRef]

40. Manchev, V.T.; Hilpert, M.; Berrou, E.; Elaib, Z.; Aouba, A.; Boukour, S.; Souquere, S.; Pierron, G.; Rameau, P.; Andrews, R.; et al. A new form of macro-thrombocytopenia induced by germ-line mutation in the PRKACG gene. Blood 2014, 124, $2554-2563$. [CrossRef]

41. Morin, G.; Bruechle, N.O.; Singh, A.R.; Knopp, C.; Jedraszak, G.; Elbracht, M.; Bre 'mond-Gignac, D.; Hartmann, K.; Sevestre, H.; Deutz, P.; et al. Gain-of-function mutation in STIM1 (P.R304W) is associated with Stormorken syndrome. Hum. Mutat. 2014, 35, 1221-1232. [CrossRef]

42. Stritt, S.; Nurden, P.; Favier, R.; Favier, M.; Ferioli, S.; Gotru, S.K.; van Eeuwijk, J.M.M.; Schulze, H.; Nurden, A.T.; Lambert, M.P.; et al. Defects in TRPM7 channel function deregulate thrombopoiesis through altered cellular $\mathrm{Mg}(2+)$ homeostasis and cytoskeletal architecture. Nat. Commun. 2016, 7, 11097. [CrossRef] [PubMed]

43. Pleines, I.; Woods, J.; Chappaz, S.; Kew, V.; Foad, N.; Ballester-Beltrán, J.; Aurbach, K.; Lincetto, C.; Lane, R.M.; Schevzov, G.; et al. Mutations in tropomyosin 4 underlie a rare form of human macrothrombocytopenia. J. Clin. Investig. 2017, 127, 814-829. [CrossRef] [PubMed]

44. Kunishima, S.; Kobayashi, R.; Itoh, T.J.; Hamaguchi, M.; Saito, H. Mutation of the beta1-tubulin gene associated with congenital macrothrombocytopenia affecting microtubule assembly. Blood 2009, 113, 458-461. [CrossRef] [PubMed]

45. Massaad, M.J.; Ramesh, N.; Geha, R.S. Wiskott-Aldrich syndrome: A comprehensive review. Ann. N. Y. Acad. Sci. 2013, 1285, 26-43. [CrossRef] [PubMed]

46. Rees, D.C.; Iolascon, A.; Carella, M.; O'marcaigh, A.S.; Kendra, J.R.; Jowitt, S.N.; Wales, J.K.; Vora, A.; Makris, M.; Manning, N.; et al. Stomatocytic haemolysis and macrothrombocytopenia (Mediterranean stomatocytosis/macrothrombocytopenia) is the haematological presentation of phytosterolaemia. Br. J. Haematol. 2005, 130, 297-309. [CrossRef] [PubMed]

47. Takenouchi, T.; Okamoto, N.; Ida, S.; Uehara, T.; Kosaki, K. Further evidence of a mutation in CDC42 as a cause of a recognizable syndromic form of thrombocytopenia. Am. J. Med. Genet. A 2016, 170, 852-855. [CrossRef]

48. Futterer, J.; Dalby, A.; Lowe, G.C.; Johnson, B.; Simpson, M.A.; Motwani, J.; Williams, M.; Watson, S.P.; Morgan, N.V. Mutation in GNE is associated with severe congenital thrombocytopenia. Blood 2018, 132, 1855-1858. [CrossRef]

49. Fletcher, S.J.; Johnson, B.; Lowe, G.C.; Bem, D.; Drake, S.; Lordkipanidzé, M. SLFN14 mutations underlie thrombocytopenia with excessive bleeding and platelet secretion defects. J. Clin. Investig. 2015, 125, 3600-3605. [CrossRef] [PubMed]

50. Turro, E.; Greene, D.; Wijgaerts, A.; Thys, C.; Lentaigne, C.; Bariana, T.K.; Westbury, S.K.; Kelly, A.M.; Selleslag, D.; Stephens, J.C.; et al. A dominant gain-of-function mutation in universal tyrosine kinase SRC causes thrombocytopenia, myelofibrosis, bleeding, and bone pathologies. Sci. Transl. Med. 2016, 8, 328ra30. [CrossRef] [PubMed]

51. Marconi, C.; Di Buduo, C.A.; LeVine, K.; Barozzi, S.; Faleschini, M.; Bozzi, V.; Palombo, F.; McKinstry, S.; Lassandro, G.; Giordano, P.; et al. Loss-of-function mutations in PTPRJ cause a new form of inherited thrombocytopenia. Blood 2019, 133, 1346-1357. [CrossRef] [PubMed]

52. Raslova, H.; Komura, E.; Le Couédic, J.P.; Larbret, F.; Debili, N.; Feunteun, J.; Danos, O.; Albagli, O.; Vainchenker, W.; Favier, R. FLI1 monoallelic expression combined with its hemizygous loss underlies Paris-Trousseau/Jacobsen thrombopenia. J. Clin. Investig. 2004, 114, 77-84. [CrossRef] [PubMed]

53. Thompson, A.A.; Woodruff, K.; Feig, S.A.; Nguyen, L.T.; Schanen, N.C. Congenital thrombocytopenia and radio-ulnar synostosis: A new familial syndrome. Br. J. Haematol. 2001, 113, 866-870. [CrossRef] [PubMed]

54. Gresele, P.; Falcinelli, E.; Giannini, S.; D’Adamo, P.; D’Eustacchio, A.; Corazzi, T.; Mezzasoma, A.M.; Di Bari, F.; Guglielmini, G.; Cecchetti, L.; et al. Dominant inheritance of a novel integrin beta3 mutation associated with a hereditary macrothrombocytopenia and platelet dysfunction in two Italian families. Haematologica 2009, 94, 663-669. [CrossRef] [PubMed]

55. Bury, L.; Zetterberg, E.; Leinøe, E.B.; Falcinelli, E.; Marturano, A.; Manni, G.; Nurden, A.T.; Gresele, P. A novel variant Glanzmann thrombasthenia due to co-inheritance of a loss- and a gain-of-function mutation of ITGB3: Evidence of a dominant effect of gain-of-function mutations. Haematologica. 2018, 103, e259-e263. [CrossRef]

56. Sabri, S.; Foudi, A.; Boukour, S.; Franc, B.; Charrier, S.; Jandrot-Perrus, M.; Farndale, R.W.; Jalil, A.; Blundell, M.P.; Cramer, E.M.; et al. Deficiency in the Wiskott-Aldrich protein induces premature proplatelet formation and platelet production in the bone marrow compartment. Blood 2006, 108, 134-140. [CrossRef]

57. Nesin, V.; Wiley, G.; Kousi, M.; Ong, E.-C.; Lehmann, T.; Nicholl, D.J.; Suri, M.; Shahrizaila, N.; Katsanis, N.; Gaffney, P.M.; et al. Activating mutations in STIM1 and ORAI1 cause overlapping syndromes of tubular myopathy and congenital miosis. Proc. Natl. Acad. Sci. USA 2014, 111, 4197-4202. [CrossRef]

58. Grosse, J.; Braun, A.; Varga-Szabo, D.; Beyersdorf, N.; Schneider, B.; Zeitlmann, L.; Hanke, P.; Schropp, P.; Mühlstedt, S.; Zorn, C.; et al. An EF hand mu-tation in Stim1 causes premature platelet activation and bleeding in mice. J. Clin. Investig. 2007, 117, 3540-3550. [CrossRef]

59. Berge, K.E.; Tian, H.; Graf, G.A.; Yu, L.; Grishin, N.V.; Schultz, J.; Kwiterovich, P.; Shan, B.; Barnes, R.; Hobbs, H.H. Accu-mulation of dietary cholesterol in sitosterolemia caused by mutations in adjacent ABC transporters. Science 2000, 290, 1771-1775. [CrossRef]

60. Su, Y.; Wang, Z.; Yang, H.; Cao, L.; Liu, F.; Bai, X.; Ruan, C. Clinical and molecular genetic analysis of a family with sitosterolemia and co-existing erythrocyte and platelet abnormalities. Haematologica 2006, 91, 1392-1395. 
61. Pisareva, V.P.; Muslimov, I.A.; Tcherepanov, A.; Pisarev, A.V. Characterization of novel ribosome-associated endoribonuclease SLFN14 from rabbit reticulocytes. Biochemistry 2015, 54, 3286-3301. [CrossRef]

62. Marconi, C.; Di Buduo, C.A.; Barozzi, S.; Palombo, F.; Pardini, S.; Zaninetti, C.; Pippucci, T.; Noris, P.; Balduini, A.; Marconi, C.; et al. SLFN14-related thrombocytopenia: Identification within a large series of patients with inherited thrombocytopenia. Thromb. Haemost. 2016, 115, 1076-1079. [CrossRef] [PubMed]

63. Eisenberg, I.; Avidan, N.; Potikha, T.; Hochner, H.; Chen, M.; Olender, T.; Barash, M.; Shemesh, M.; Sadeh, M.; GrabovNardini, G.; et al. The UDP-N-acetylglucosamine 2-epimerase/ $\mathrm{N}$-acetylmannosamine kinase gene is mutated in recessive hereditary inclusion body myopathy. Nat. Genet. 2001, 29, 83-87. [CrossRef] [PubMed]

64. Rodeghiero, F.; Pabinger, I.; Ragni, M.; Abdul-Kadir, R.; Berntorp, E.; Blanchette, V.; Bodó, I.; Casini, A.; Gresele, P.; Lassila, R.; et al. Fundamentals for a systematic approach to mild and moderate inherited bleeding disorders: A EHA consensus report. Hemasphere 2019, 3, e286. [CrossRef] [PubMed]

65. Gresele, P.; Orsini, S.; Noris, P.; Falcinelli, E.; Alessi, M.C.; Bury, L.; Borhany, M.; Santoro, C.; Glembotsky, A.C.; Cid, A.R.; et al. BATVAL study investigators. Validation of the ISTH/SSC bleeding assessment tool for inherited platelet disorders: A communication from the Platelet Physiology SSC. J. Thromb. Haemost. 2020, 18, 732-739. [CrossRef] [PubMed]

66. Balduini, C.L.; Cattaneo, M.; Fabris, F.; Gresele, P.; Iolascon, A.; Pulcinelli, F.M.; Savoia, A. Inherited thrombocytopenias: A proposed diagnostic algorithm from the Italian Gruppo di Studio delle Piastrine. Haematologica 2003, 88, 582-592. [PubMed]

67. Noris, P.; Pecci, A.; Di Bari, F.; Di Stazio, M.T.; Di Pumpo, M.; Ceresa, I.F.; Arezzi, N.; Ambaglio, C.; Savoia, A.; Balduini, C.L. Application of a diagnostic algorithm for inherited thrombocytopenias to 46 consecutive patients. Haematologica 2004, 89, 1219-1225. [PubMed]

68. Zaninetti, C.; Greinacher, A. Diagnosis of Inherited Platelet Disorders on a Blood Smear. J. Clin. Med. 2020, 9, 539. [CrossRef]

69. Bury, L.; Falcinelli, E.; Gresele, P. Inherited Platelet Function Disorders: Algorithms for Phenotypic and Genetic Investigation. Semin. Thromb. Hemost. 2016, 42, 292-305. [CrossRef]

70. Podda, G.M.; Pugliano, M.; Femia, E.A.; Mezzasoma, A.M.; Gresele, P.; Carpani, G.; Cattaneo, M. The platelet count in EDTAanticoagulated blood from patients with thrombocytopenia may be underestimated when measured in routine laboratories. Am. J. Hematol. 2012, 87, 727-728. [CrossRef]

71. Noris, P.; Biino, G.; Pecci, A.; Civaschi, E.; Savoia, A.; Seri, M.; Melazzini, F.; Loffredo, G.; Russo, G.; Bozzi, V.; et al. Platelet diameters in inherited thrombocytopenias: Analysis of 376 patients with all known disorders. Blood 2014, 124, e4-e10. [CrossRef]

72. Monteferrario, D.; Bolar, N.A.; Marneth, A.E.; Hebeda, K.M.; Bergevoet, S.M.; Veenstra, H.; Laros-van Gorkom, B.A.; MacKenzie, M.A.; Khandanpour, C.; Botezatu, L.; et al. A dominant-negative GFI1B mutation in the gray platelet syndrome. N. Engl. J. Med. 2014, 370, 245-253. [CrossRef] [PubMed]

73. Gresele, P.; Bury, L.; Mezzasoma, A.M.; Falcinelli, E. Platelet function assays in diagnosis: An update. Expert Rev. Hematol. 2019, 12, 29-46. [CrossRef] [PubMed]

74. Gresele, P.; Falcinelli, E.; Bury, L. Laboratory diagnosis of clinically relevant platelet function disorders. Int. J. Lab. Hematol. 2018, 40, 34-45. [CrossRef] [PubMed]

75. Mumford, A.D.; Frelinger, A.L., 3rd; Gachet, C.; Gresele, P.; Noris, P.; Harrison, P.; Mezzano, D. A review of platelet secretion assays for the diagnosis of inherited platelet secretion disorders. Thromb. Haemost. 2015, 114, 14-25. [CrossRef] [PubMed]

76. Othman, M.; Gresele, P. Guidance on the diagnosis and management of platelet-type von Willebrand disease: A communication from the Platelet Physiology Subcommittee of the ISTH. J. Thromb. Haemost. 2020, 18, 1855-1858. [CrossRef] [PubMed]

77. Giannini, S.; Cecchetti, L.; Mezzasoma, A.M.; Gresele, P. Diagnosis of platelet-type von Willebrand disease by flow cytometry. Haematologica 2010, 95, 1021-1024. [CrossRef] [PubMed]

78. Sims, M.C.; Mayer, L.; Collins, J.H.; Bariana, T.K.; Megy, K.; Lavenu-Bombled, C.; Seyres, D.; Kollipara, L.; Burden, F.S.; Greene, D.; et al. Novel manifestations of immune dysregulation and granule defects in gray platelet syndrome. Blood 2020, 136, 1956-1967. [CrossRef] [PubMed]

79. Stevenson, W.S.; Rabbolini, D.J.; Beutler, L.; Chen, Q.; Gabrielli, S.; Mackay, J.P.; Brighton, T.A.; Ward, C.M.; Morel-Kopp, M.C. Paris-Trousseau thrombocytopenia is phenocopied by the autosomal recessive inheritance of a DNA-binding domain mutation in FLI1. Blood 2015, 126, 2027-2030. [CrossRef]

80. Pecci, A.; Biino, G.; Fierro, T.; Bozzi, V.; Mezzasoma, A.; Noris, P.; Ramenghi, U.; Loffredo, G.; Fabris, F.; Momi, S.; et al. Alteration of Liver Enzymes Is a Feature of the Myh9-Related Disease Syndrome. PLoS ONE 2012, 7, e35986. [CrossRef]

81. Noris, P.; Pecci, A. Hereditary thrombocytopenias: A growing list of disorders. Hematology 2017, 2017, 385-399. [CrossRef]

82. Simeoni, I.; Stephens, J.C.; Hu, F.; Deevi, S.V.V.; Megy, K.; Bariana, T.K.; Lentaigne, C.; Schulman, S.; Sivapalaratnam, S.; Vries, M.J.A.; et al. A high-throughput sequencing test for diagnosing inherited bleeding, thrombotic, and platelet disorders. Blood 2016, 127, 2791-2803. [CrossRef] [PubMed]

83. Downes, K.; Megy, K.; Duarte, D.; Vries, M.; Gebhart, J.; Hofer, S.; Shamardina, O.; Deevi, S.V.V.; Stephens, J.; Mapeta, R.; et al. Diagnostic high-throughput sequencing of 2396 patients with bleeding, thrombotic, and platelet disorders. Blood 2019, 134, 2082-2091. [CrossRef] [PubMed]

84. Megy, K.; Downes, K.; Simeoni, I.; Bury, L.; Morales, J.; Mapeta, R.; Bellissimo, D.B.; Bray, P.F.; Goodeve, A.C.; Gresele, P.; et al. Subcommittee on Genomics in Thrombosis and Hemostasis. Cu-rated disease-causing genes for bleeding, thrombotic, and platelet disorders: Communication from the SSC of the ISTH. J. Thromb. Haemost. 2019, 17, 1253-1260. [CrossRef] [PubMed] 
85. Downes, K.; Borry, P.; Ericson, K.; Gomez, K.; Greinacher, A.; Lambert, M.; Leinoe, E.; Noris, P.; Van Geet, C.; Freson, K. Subcommittee on Genomics in Thrombosis, Hemostasis. Clinical management, ethics and informed consent related to multi-gene panel-based high throughput sequencing testing for platelet disorders: Communication from the SSC of the ISTH. J. Thromb. Haemost. 2020, 18, 2751-2758. [CrossRef] [PubMed]

86. Richards, S.; Aziz, N.; Bale, S.; Bick, D.; Das, S.; Gastier-Foster, J.; Grody, W.W.; Hegde, M.; Lyon, E.; Spector, E.; et al. ACMG Laboratory Quality Assurance Committee. Standards and guidelines for the interpretation of sequence variants: A joint consensus recommendation of the American College of Medical Genetics and Genomics and the Association for Molecular Pathology. Genet. Med. 2015, 17, 405-424. [CrossRef] [PubMed]

87. Drachman, J.G. Inherited thrombocytopenia: When a low platelet count does not mean ITP. Blood 2004, 103, 390-398. [CrossRef]

88. Johnson, B.; Lowe, G.C.; Futterer, J.; Lordkipanidzé, M.; Macdonald, D.; Simpson, M.A.; Guiú, I.S.; Drake, S.; Bem, D.; Leo, V.; et al. Whole exome sequencing identifies genetic variants in inherited thrombocytopenia with secondary qualitative function defects. Haematologica 2016, 101, 1170-1179. [CrossRef]

89. Gresele, P.; Falcinelli, E.; Bury, L. Inherited platelet disorders in women. Thromb. Res. 2019, 181, S54-S59. [CrossRef]

90. Balduini, C.L.; Melazzini, F.; Pecci, A. Inherited Thrombocytopenias. In Platelets in Thrombotic and Non Thrombotic Disorders; Gresele, P., Kleiman, N.S., Lopez, J.A., Page, C.P., Eds.; Springer Gmbh: Cambridge, UK, 2017; pp. 727-747.

91. Kaur, H.; Ozelo, M.; Scovil, S.; James, P.D.; Othman, M. Systematic analysis of bleeding phenotype in PT-VWD compared to type 2B VWD using an electronic bleeding questionnaire. Clin. Appl. Thromb. Hemost. 2014, 20, 765-771. [CrossRef]

92. Nurden, P.; Nurden, A.; Favier, R.; Gleyze, M. Management of pregnancy for a patient with the new syndromic macrothrombocytopenia, DIAPH1-related disease. Platelets 2018, 29, 737-738. [CrossRef]

93. Orsini, S.; Noris, P.; Bury, L.; Heller, P.G.; Santoro, C.; Kadir, R.A.; Butta, N.C.; Falcinelli, E.; Cid, A.R.; Fabris, F.; et al. European Hematology Association-Scientific Working Group (EHA-SWG) on thrombocytopenias and platelet function disorders. Bleeding risk of surgery and its pre-vention in patients with inherited platelet disorders. Haematologica 2017, 102, 1192-1203. [CrossRef] [PubMed]

94. Morgan, N.V.; Daly, M.E. Gene of the issue: RUNX1 mutations and inherited bleeding. Platelets 2017, 28, 208-210. [CrossRef] [PubMed]

95. Melazzini, F.; Zaninetti, C.; Balduini, C.L. Bleeding is not the main clinical issue in many patients with inherited thrombocytopaenias. Haemophilia 2017, 23, 673-681. [CrossRef] [PubMed]

96. Pecci, A.; Klersy, C.; Gresele, P.; Lee, K.J.; De Rocco, D.; Bozzi, V.; Russo, G.; Heller, P.G.; Loffredo, G.; Ballmaier, M.; et al. MYH9-related disease: A novel prognostic model to predict the clinical evolution of the disease based on genotype-phenotype correlations. Hum. Mutat. 2014, 35, 236-247. [CrossRef]

97. Bury, L.; Megy, K.; Stephens, J.C.; Grassi, L.; Greene, D.; Gleadall, N.; Althaus, K.; Allsup, D.; Bariana, T.K.; Bonduel, M.; et al. Next-generation sequencing for the diagnosis of MYH9 -RD: Predicting pathogenic variants. Hum. Mutat. 2019, 41, $277-290$. [CrossRef]

98. Falcinelli, E.; Bury, L.; Gresele, P. Inherited platelet function disorders. Hämostaseologie 2016, 36, 265-278. [CrossRef]

99. Makris, M.; Conlon, C.P.; Watson, H.G. Immunization of patients with bleeding disorders. Haemophilia 2003, 9, 541-546. [CrossRef]

100. Bolton-Maggs, P.; Chalmers, E.A.; Collins, P.W.; Harrison, P.; Kitchen, S.; Liesner, R.J.; Minford, A.; Mumford, A.D.; Parapia, L.A.; Perry, D.J.; et al. A review of inherited platelet disorders with guidelines for their management on behalf of the UKHCDO. Br. J. Haematol. 2006, 135, 603-633. [CrossRef]

101. Buijs, A.; Poddighe, P.; van Wijk, R.; van Solinge, W.; Borst, E.; Verdonck, L.; Hagenbeek, A.; Pearson, P.; Lokhorst, H. A novel CBFA2 single-nucleotide mutation in familial platelet disorder with propensity to develop myeloid malig-nancies. Blood 2001, 98, 2856-2858. [CrossRef]

102. Demers, C.; Derzko, C.; David, M.; Douglas, J. Gynaecological and obstetric management of women with inherited bleeding disorders. Int. J. Gynaecol. Obstet. 2006, 95, 75-87. [CrossRef]

103. Sogut, O.; Erdogan, M.O.; Kose, R.; Boleken, M.E.; Kaya, H.; Gokdemir, M.T.; Ozgonul, A.; Iynen, I.; Albayrak, L.; Dokuzoglu, M.A. Hemostatic Efficacy of a Traditional Medicinal Plant Extract (Ankaferd Blood Stopper) in Bleeding Control. Clin. Appl. Thromb. 2015, 21, 348-353. [CrossRef] [PubMed]

104. Harrison, P. Subcommittee on Platelet Physiology. The use of platelets in regenerative medicine and proposal for a new classification system: Guidance from the SSC of the ISTH. J. Thromb. Haemost. 2018, 16, 1895-1900. [CrossRef] [PubMed]

105. Nurden, P.; Youlouz-Marfak, I.; Siberchicot, F.; Kostrzewa, E.; Andia, I.; Anitua, E.; Nurden, A.T. Use of autologous platelet-rich clots for the prevention of local injury bleeding in patients with severe inherited mucocutaneous bleeding disorders. Haemophilia 2011, 17, 620-624. [CrossRef] [PubMed]

106. Kumar, S.; Randhawa, M.S.; Ganesamoni, R.; Singh, S.K. Tranexamic Acid Reduces Blood Loss During Percutaneous Nephrolithotomy: A Prospective Randomized Controlled Study. J. Urol. 2013, 189, 1757-1761. [CrossRef] [PubMed]

107. Vujkovac, B.; Sabovic, M. A successful treatment of life-threatening bleeding from polycystic kidneys with anti-fibrinolytic agent tranexamic acid. Blood Coagul. Fibrinolysis 2006, 17, 589-591. [CrossRef]

108. Dunn, C.J.; Goa, K.L. Tranexamic acid: A review of its use in surgery and other indications. Drugs 1999, 57, 1005-1032. [CrossRef]

109. Colucci, G.; Stutz, M.; Rochat, S.; Conte, T.; Pavicic, M.; Reusser, M.; Giabbani, E.; Huynh, A.; Thürlemann, C.; Keller, P.; et al. The effect of desmopressin on platelet function: A selective enhancement of procoagulant COAT platelets in patients with primary platelet function defects. Blood 2014, 123, 1905-1916. [CrossRef] 
110. Tosetto, A.; Balduini, C.L.; Cattaneo, M.; De Candia, E.; Mariani, G.; Molinari, A.C.; Rossi, E.; Siragusa, S. Italian Society for Haemostasis and Thrombosis. Management of bleeding and of invasive procedures in patients with platelet disorders and/or thrombocytopenia: Guidelines of the Italian Society for Haemostasis and Thrombosis (SISET). Thromb. Res. 2009, 124, 13-18. [CrossRef]

111. Sehbai, A.S.; Abraham, J.; Brown, V.K. Perioperative management of a patient with May-Hegglin anomaly requiring craniotomy. Am. J. Hematol. 2005, 79, 303-308. [CrossRef]

112. Poon, M.C. The evidence for the use of recombinant human activated factor VII in the treatment of bleeding patients with quantitative and qualitative platelet disorders. Transfus. Med. Rev. 2007, 21, 223-236. [CrossRef]

113. Franchini, M. The use of recombinant activated factor VII in the treatment of bleeding patients with quantitative and qualitative platelet disorders. Blood Transfus. 2009, 7, 24-28. [PubMed]

114. Pecci, A.; Gresele, P.; Klersy, C.; Savoia, A.; Noris, P.; Fierro, T.; Bozzi, V.; Mezzasoma, A.M.; Melazzini, F.; Balduini, C.L. Eltrombopag for the treatment of the inherited thrombocytopenia deriving from MYH9 mutations. Blood 2010, 116, 5832-5837. [CrossRef] [PubMed]

115. Zaninetti, C.; Gresele, P.; Bertomoro, A.; Klersy, C.; De Candia, E.; Veneri, D.; Barozzi, S.; Fierro, T.; Alberelli, M.A.; Musella, V.; et al. Eltrombopag for the treatment of inherited thrombocytopenias: A phase 2 clinical trial. Haematologica 2020, 105, 820-828. [CrossRef]

116. Gerrits, A.J.; Leven, E.A.; Frelinger, A.L.; Brigstocke, S.L.; Berny-Lang, M.A.; Mitchell, W.B.; Revel-Vilk, S.; Tamary, H.; Carmichael, S.L.; Barnard, M.R.; et al. Effects of eltrombopag on platelet count and platelet activation in Wiskott-Aldrich syndrome/X-linked thrombocytopenia. Blood 2015, 126, 1367-1378. [CrossRef] [PubMed]

117. Pecci, A.; Verver, E.J.; Schlegel, N.; Canzi, P.; Boccio, C.M.; Platokouki, H.; Krause, E.; Benazzo, M.; Topsakal, V.; Greinacher, A. Cochlear implantation is safe and effective in patients with MYH9-related disease. Orphanet. J. Rare Dis. 2014, 9, 100. [CrossRef]

118. Favier, R.; Feriel, J.; Favier, M.; Denoyelle, F.; Martignetti, J.A. First Successful Use of Eltrombopag Before Surgery in a Child With MYH9-Related Thrombocytopenia. Pediatrics 2013, 132, e793-e795. [CrossRef]

119. Zaninetti, C.; Barozzi, S.; Bozzi, V.; Gresele, P.; Balduini, C.L.; Pecci, A. Eltrombopag in preparation for surgery in patients with severe MYH9-related thrombocytopenia. Am. J. Hematol. 2019, 94, e199-e201. [CrossRef]

120. Paciullo, F.; Bury, L.; Gresele, P. Eltrombopag to allow chemotherapy in a patient with MYH9-related inherited thrombocytopenia and pancreatic cancer. Int. J. Hematol. 2020, 112, 1-3. [CrossRef]

121. Moratto, D.; Giliani, S.; Bonfim, C.; Mazzolari, E.; Fischer, A.; Ochs, H.D.; Cant, A.J.; Thrasher, A.J.; Cowan, M.J.; Albert, M.H.; et al. Long-term outcome and lineage-specific chimerism in 194 patients with Wiskott-Aldrich syndrome treated by hematopoietic cell transplantation in the period 1980-2009: An international collaborative study. Blood 2011, 118, 1675-1684. [CrossRef]

122. Ballmaier, M.; Germeshausen, M. Congenital Amegakaryocytic Thrombocytopenia: Clinical Presentation, Diagnosis, and Treatment. Semin. Thromb. Hemost. 2011, 37, 673-681. [CrossRef]

123. Bosticardo, M.; Marangoni, F.; Aiuti, A.; Villa, A.; Grazia Roncarolo, M. Recent advances in understanding the pathophysiology of Wiskott-Aldrich syndrome. Blood 2009, 113, 6288-6295. [CrossRef] [PubMed]

124. Locatelli, F.; Rossi, G.; Balduini, C. Hematopoietic stem-cell transplantation for the Bernard-Soulier syndrome. Ann. Intern. Med. 2003, 138, 79. [CrossRef] [PubMed]

125. Oshima, K.; Imai, K.; Albert, M.H.; Bittner, T.C.; Strauss, G.; Filipovich, A.H.; Morio, T.; Kapoor, N.; Dalal, J.; Schultz, K.R.; et al. Hematopoietic stem cell transplantation for X-linked thrombo-cytopenia with mutations in the WAS gene. J. Clin. Immunol. 2015, 35, 15-21. [CrossRef] [PubMed]

126. Aiuti, A.; Biasco, L.; Scaramuzza, S.; Ferrua, F.; Cicalese, M.P.; Baricordi, C.; Dionisio, F.; Calabria, A.; Giannelli, S.; Castiello, M.C.; et al. Lentiviral Hematopoietic Stem Cell Gene Therapy in Patients with Wiskott-Aldrich Syndrome. Science 2013, 341, 1233151. [CrossRef] [PubMed]

127. Hacein-Bey Abina, S.; Gaspar, H.B.; Blondeau, J.; Caccavelli, L.; Charrier, S.; Buckland, K.; Picard, C.; Six, E.; Himoudi, N.; Gilmour, K.; et al. Outcomes following gene therapy in patients with severe Wiskott-Aldrich syndrome. JAMA 2015, 313, 1550-1563. [CrossRef]

128. Pala, F.; Morbach, H.; Castiello, M.C.; Schickel, J.N.; Scaramuzza, S.; Chamberlain, N.; Cassani, B.; Glauzy, S.; Romberg, N.; Candotti, F.; et al. Lentiviral mediated gene therapy restores B cell tolerance in Wiskott-Aldrich syndrome patients. J. Clin. Investig. 2015, 125, 3941-3951. [CrossRef]

129. Kanaji, S.; Kuether, E.L.; Fahs, S.A.; Schroeder, J.A.; Ware, J.; Montgomery, R.R.; Shi, Q. Correction of murine Bernard-Soulier syndrome by lentivirus-mediated gene therapy. Mol. Ther. 2012, 20, 625-632. [CrossRef]

130. Albert, M.H.; Bittner, T.C.; Nonoyama, S.; Notarangelo, L.D.; Burns, S.; Imai, K.; Espanol, T.; Fasth, A.; Pellier, I.; Strauss, G.; et al. X-linked thrombocytopenia (XLT) due to WAS mutations: Clinical characteristics, long-term outcome, and treatment options. Blood 2010, 115, 3231-3238. [CrossRef]

131. Mullen, C.A.; Anderson, K.D.; Blaese, R.M. Splenectomy and/or bone marrow transplantation in the management of the Wiskott-Aldrich syndrome: Long-term follow-up of 62 cases. Blood 1993, 82, 2961-2966. [CrossRef] 